\title{
The Erosion of Affirmative Action and its Consequences for the Black-White Educational Attainment Gap
}

\author{
Ronald Caldwell Jr.
}

\section{INTRODUCTION}

The disparity in economic outcomes between whites and blacks in the United States has long been an important social and political issue. While there are many factors contributing to this economic gulf, a crucial element is undoubtedly the large and pervasive gap that exists in the level of educational attainment between whites and blacks. It is wellknown that higher levels of educational attainment are correlated with greater earnings, lower unemployment, and greater levels of labor force attachment. Therefore, addressing the issue of inequality in educational attainment, particularly that of higher education, may provide substantial long-term benefits toward ultimately creating economic and social equality.

Over the past several decades many colleges and universities have employed affirmative action in their admissions programs in order to foster more campus diversity and to provide greater educational opportunities for underrepresented minorities. The mid-1990s, however, saw the beginnings of a significant affirmative action backlash that has culminated in the removal of affirmative action in several states. The use of affirmative action in university admissions has now endured more than a decade of legal, political, and social challenges and will likely remain a topic of significant debate in the near future. The outcome of this debate will likely have important implications for the future educational opportunities of underrepresented minorities, and may ultimately play a significant long-term role in the possible bridging of the black-white gap in economic outcomes.

* Assistant Professor, Department of Economics, University of Kansas; Ph.D., Economics, University of Washington. 


\section{RACIAL DISPARITIES IN EDUCATIONAL ATTAINMENT}

Figure 1 provides an illustration of the educational attainment gap for the 2005 U.S. population age twenty-five and older. The Figure shows the percentage of each of four racial/ethnic groups (non-Hispanic whites, non-Hispanic blacks, Asians, and Hispanics) that have achieved various levels of educational attainment ranging from less than a high school education to successful completion of a doctoral degree or advanced professional degree. Several things are apparent based on this data. First, the percentage of Hispanic adults who have less than a high school education is greater than forty percent. Much of this may be due to recent waves of immigration from countries where completion of twelve years of education is not the norm. Also, children of recent immigrants born in the United States are still progressing through school and may significantly transform these numbers over time as they age.

Second, the overall educational level of adult Asian-Americans within the population is extraordinarily high. Approximately fifty percent of the Asian population in the United States has a bachelor's degree or higher, and Asians in the United States have higher rates of bachelor's completion, master's completion, doctoral completion, and completion of advanced professional degrees than do any other racial or ethnic group.

Finally, and most relevant to the current discussion, is that the educational attainment of blacks lags significantly behind that of white or Asian America - the impact of which may serve to exacerbate a cycle of lower lifetime earnings and in turn fewer educational opportunities for future generations.

A more dynamic illustration of the black-white educational attainment gap is shown in Figure 2, which plots the percentage of twenty-five to twenty-nine-year-olds that had completed at least four years of college for both blacks and whites since 1964. There is a readily apparent upward trend over time in the percentage of blacks who had completed four years of college by the age of twenty-nine. Whites, however, also show substantial increases in the proportion earning a four-year degree over the past forty years, suggesting that black increases may be part of an overall trend.

Figure 3 shows the black-white gap in percent completion of four years of college by age twenty-nine over time. While the number of blacks earning four-year degrees has increased in absolute terms over the past forty years, there apparently have been little real gains in bridging the educational attainment gap despite the presence of affirmative action. 


\section{THE IMPACT OF EDUCATIONAL ATTAINMENT ON EARNINGS, UNEMPLOYMENT, AND LABOR FORCE PARTICIPATION FOR BLACKS}

It is very difficult to determine the causal relationship between years of schooling and its impact on earnings, labor force participation, and unemployment. Quantitative analysis in this area is plagued by unobservable characteristics, incomplete environmental context, and selection bias. Certain aspects can be controlled for by using sophisticated statistical techniques, but this really serves more to limit the plausible alternative explanations than it does to elicit definitive causal relationships. This being said, however, there does exist a very strong correlation between years of schooling and higher earnings, higher labor force participation, and lower levels of unemployment. Given the large gap that exists in educational attainment for blacks relative to whites, there are undoubtedly substantial gains that can be had by encouraging greater minority involvement in higher education.

In 2005 the median level of earnings for black workers age twentyfive and above was $\$ 27,101$ while the median level of earnings for white workers was $\$ 33,029$, approximately $21.9 \%$ higher than for blacks. These values, however, do not control for differences in the level of educational attainment between these two groups. ${ }^{1}$ Median earnings for black and white workers age twenty-five and above per level of educational attainment for the year 2005 are shown in Figure 4. In all cases, median white earnings are significantly greater than for blacks. ${ }^{2}$ However, the within-educational-group differences are more modest, with the exception of professional and doctoral degree earners, than found when comparing black and white earnings pooled across all education levels. When comparing workers with a bachelor's degree, for instance, the median earnings were $\$ 41,571$ for blacks in 2005 and were $\$ 43,833$ for whites, a difference of approximately 5.4\%. Additionally, despite the lower levels of median compensation at all education levels relative to whites, blacks do receive a more substantial increase in earnings for higher levels of educational attainment. For instance, the median level of earnings for blacks with only a high school education in 2005 was approximately $\$ 22,379$, resulting in an increase of more than $\$ 19,000$ per year for having a bachelor's degree. For whites, the

1. Mean earnings show a greater level of disparity with mean earnings for blacks in 2005 at $\$ 33,338$ and $\$ 44,604$ for whites, a difference of approximately $34.8 \%$. Source: U.S. Census Bureau.

2. A portion of the differences in median earnings may be due to labor market discrimination, however, occupational selection, regional differences in wages and employment levels, quality of schooling, and skill levels are also relevant factors. 
economic benefit of having a bachelor's degree relative to having a high school degree only was approximately $\$ 16,500$ per year. While it would be a fallacy to assume that increasing education levels for all blacks would result in such substantial increases in earnings, it is certainly plausible that encouraging greater enrollment among minorities in colleges and universities may bridge much of the current black-white earnings gap.

A similar story could be told for unemployment rates. Figure 5 shows the annual unemployment rate for blacks and whites age twentyfive and older for the past seventeen years. While unemployment rates do tend to be greater for blacks than for whites, it should be remembered that blacks are disproportionately more likely to have only a high school education or less, and this has a significant impact on unemployment, as Figure 6 illustrates. Figure 7 shows a 2007 static view of the unemployment rates by race and educational attainment. Unemployment among blacks is significantly higher than for other groups at lower levels of educational attainment, but drops substantially with more years of schooling, and reaches parity with Asian-Americans for those with a bachelor's degree or higher.

Trends over the past several years suggest an even more optimistic upside to the potential impact of increasing educational attainment among blacks with regard to labor-force participation rates. Figure 8 shows the annual labor-force participation rates over the past seventeen years broken down by education level. Labor-force participation rates within education groups are fairly stable over time, but there are substantial differences between groups. Individuals with at least a bachelor's degree have labor force participation rates of approximately eighty percent, while those with only a high school degree have labor force participation rates of approximately sixty-five percent, and those with less than a high school degree have rates of less than fifty percent. ${ }^{3}$ In aggregate, blacks tend to have lower levels of labor-force attachment than do whites, but this does not control for the disproportionately lower levels of educational attainment among blacks. Figure 9 shows the average annual labor force participation rate for the past seventeen years for both blacks and whites broken down by education level. Among those with higher levels of education, blacks tend to have, on average, greater levels of labor-force participation than do whites.

3. There are many reasons why individuals may leave the labor force, however much of the low labor force participation among lower-educated individuals can be attributed to an inability to find work which leads to discouraged candidates dropping out of the labor force. 
These data suggest that greater levels of educational attainment can have a major economic impact regardless of race/ethnicity. Blacks, however, appear to be the group that receives the greatest additional benefit from more years of education. Annual earnings for highly educated blacks remain lower than for whites of similar educational background, but the increase in earnings from having a bachelor's degree relative to a high school degree are greater for blacks than for whites. Additionally, the apparent beneficial impact of higher education on unemployment rates and labor force participation rates seems to disproportionately favor blacks relative to other races. Policies, therefore, that either promote or hinder the representation of blacks in institutions of higher education should be carefully analyzed given the apparent overall economic importance of this issue.

\section{THE EROSION OF AFFIRMATIVE ACTION IN UNIVERSITY ADMISSIONS}

The legal basis for the use of race-based admissions criteria by colleges and universities prior to 1996 was derived, in part, from the 1978 U.S. Supreme Court decision Regents of the University of California v. Bakke. ${ }^{4}$ The decision established the constitutionality of using race as a factor in college admissions, stating that colleges and universities may use admissions programs that take into account race in order to help foster diversity, provided that quotas were not explicitly used. This ruling set the stage for the inclusion of race in the decisionmaking process for many academic admissions programs for the following twenty years.

The 1990s, however, saw the beginnings of significant erosion in the ability of universities to use race explicitly in their admissions decisions. This erosion, primarily beginning with California's Proposition $209^{5}$ and the Hopwood v. Texas $^{6}$ decision in 1996, has continued to the present day and opposition to the use of affirmative action remains strong in many areas of the country. Claims of unfair advantage, preferential treatment, and reverse discrimination have become mainstays in the ongoing debate and illustrate just how divided the country remains over the issue of educational inequality.

On March 18, 1996, the U.S. Court of Appeals for the Fifth Circuit, covering Louisiana, Mississippi, and Texas, ruled on a challenge to the

\footnotetext{
4. 438 U.S. 265 (1978).

5. CAL. CONST. art. I, $\S 31$.

6. 78 F.3d 932 (5th Cir. 1996), abrogated by Grutter v. Bollinger, 539 U.S. 306 (2003), as recognized in Bourdais v. New Orleans, 485 F.3d 294, 300 n.7 (5th Cir. 2007).
} 
University of Texas School of Law's admissions policies that included targeted percentages of Hispanic and black students. ${ }^{7}$ The court held that the affirmative action programs used at the University of Texas were unconstitutional and that educational diversity should not be recognized as a compelling state interest. ${ }^{8}$ The U.S. Supreme Court refused to hear the case on appeal, ${ }^{9}$ effectively overturning the Bakke precedent within the Fifth Circuit, apparently making the use of race in admissions policies illegal in Texas, Louisiana, and Mississippi. In 1997, the Texas Attorney General announced that all universities in Texas should adopt race-neutral admissions criteria, which was followed by a state law setting uniform admissions policies for all universities within Texas. This law-which took effect in 1998 - forbade the explicit use of race in admissions policies, but did include automatic admission into Texas public universities for all high school seniors graduating in the top ten percent of their class.

In November of 1996, voters in California passed Proposition 209, which banned all California affirmative action programs in public college admissions, government hiring, and government contracting, with $54 \%$ of the overall vote. According to exit polling data, voting for Proposition 209 largely followed racial lines. Approximately $59.3 \%$ of white voters, $37.4 \%$ of Hispanic voters, and $18.2 \%$ of black voters voted in support of the ban. ${ }^{10}$ The proposition took effect on November 3, 1997, after being delayed in the courts for almost a year. ${ }^{11}$

There have been other state-level prohibitions or challenges on the use of affirmative action policies for university admissions over the past decade. Washington state passed Initiative 200, which eliminated affirmative action, in November of $1998 .^{12}$ Florida passed laws that banned race and gender preferences in admissions to certain schools in 2001. ${ }^{13}$ The state of Michigan has had a pair of cases, Gratz $v$. Bollinger ${ }^{14}$ and Grutter v. Bollinger, ${ }^{15}$ brought before the U.S. Supreme Court regarding the use of race in admissions policies. In the latter case,

7. Id. at 934 .

8. Id. at $934-35$.

9. Texas v. Hopwood, 518 U.S. 1033 (1996) (mem.).

10. R. Michael Alvarez \& Lisa García Bedolla, The Revolution Against Affirmative Action in California: Racism, Economics, and Proposition 209, 4 ST. POL. \& POL'Y Q 1, 14 (data taken from Voter News Service exit polling data).

11. CAL. CONST. art. I, § 31 .

12. See Wash. Rev. Code AnN. § 49.60.400(1) (West 2008)

13. See Fla. Stat. ANN. $\S 1004.39$ and 1004.40 (West 2008).

14. 539 U.S. 244 (2003).

15. 539 U.S. 306 (2003). 
the Court upheld the University of Michigan Law School's admissions policy and effectively overturned the Hopwood $v$. Texas decision. ${ }^{16}$

\section{THE IMPACT OF PROPOSITION 209 AND HOPWOOD ON APPLICATION AND ADMISSION RATES FOR BLACKS}

Application and admissions data for the University of California system of schools suggests that the UC system as a whole was greatly affected by the passage of Proposition 209, with the greatest impact occurring at the flagship schools: UC Berkeley and UCLA. The flagship Texas university, the University of Texas at Austin, showed a less substantial impact by Hopwood, mitigated perhaps by the inclusion of the top-ten-percent plan that closely followed the decision.

The University of California system is comprised of nine campuses located in Berkeley, Davis, Irvine, Los Angeles, Merced, Riverside, San Diego, Santa Barbara, and Santa Cruz. In the fall of 2007, the University-wide number of first-time applications received from California residents totaled 83,969 , with 69,611 of the applicants being admitted, for an admit rate of $82.9 \%$. The most selective campuses in the system are Berkeley and UCLA, both with 2007 admit rates of $23.9 \%$. Among the 83,969 total applicants in 2007, nearly 60\% were minorities (American Indian, black, Hispanic, or Asian), so the system does provide an interesting test case for the impact of removing affirmative action. Descriptive statistics for application, admittance, and enrollment numbers by race/ethnicity and year for the UC system can be found in Tables A1 to A6 in the appendix, and statistics for UC Berkeley, UCLA, and UT Austin are shown in Tables A7 to A13.

Figure 10 illustrates the trends in admissions rates for the UC system by race/ethnicity for the years leading up to the end of affirmative action and the years immediately following. Proposition 209 became law in November of 1997, so the first affected entering class was the fall 1998 cohort. In the fall of 1997, the admit rate for California resident blacks was $72.7 \%$. In 1998 the admit rate for blacks in California fell to $63.6 \%$. Hispanics also experienced a decline in admission rates, although not quite as pronounced as for blacks, as the number of Hispanics admitted fell from $82.8 \%$ in 1997 to $75.5 \%$ in 1998. During that same period, the admission rates for whites and Asians both increased slightly from $81.8 \%$ and $84.2 \%$ respectively in 1997 to $83.8 \%$ and $85 \%$ in the fall of 1998 .

16. See id. at $328-29$. 
Figure 11 shows the black-white admissions rate gap for the UC system for the years 1994 to 2004 . The gap in admissions rates was approximately 5 to $10 \%$ in the years leading up to the end of affirmative action. The year affirmative action ended, however, the gap more than doubled and has since remained around 15 to $20 \%$. The percentage of total admits who were black also fell dramatically around the time of the end of affirmative action and has continued to remain low, as Figure 12 illustrates.

While year to year aggregate admissions, applications, and admit rates provide some information, they do not control for changing demographics within the population that might provide an alternative explanation for the significant declines experienced by blacks around the time of the policy change. A more informative approach would be the percentage of the total freshman-age population within the state who were applying and being admitting each year into the UC system of universities. In an attempt to capture this, I use census data on the size of the population in California by race/ethnicity who were age eighteen as of July 1 of the year of prospective enrollment. Figures 13 and 14 show application and admit rates for blacks as a percentage of the total eighteen-year-old black population for years 1994 to 1999.

The proportion of the eighteen-year-old black population applying to the UC system began showing a decline as early as 1997, a year before Proposition 209 became binding. This is not surprising since the measure passed in November of 1996 and had been under debate and litigation during the year of 1997. This suggests that blacks may have been responding to the anticipated end of affirmative action by altering their application patterns in advance of actual implementation. The admissions rate per population also fell slightly in 1997, presumably as a result of the drop in application rates, and fell more in 1998 once the amendment took effect. This pattern suggests that not only were universities admitting fewer blacks after the policy change, but that the prospective students were also altering their behavior in response to the ending of affirmative action by applying at a lower rate than in the years prior to the policy change.

The more selective University of California campuses showed even sharper declines for blacks following the implementation of Proposition 209. Figures 15-17 show the admissions rates by race/ethnicity for firsttime California resident admissions to UC Berkeley and UCLA for the years 1994 to 2004. In the year that Proposition 209 took effect, the admissions rate for blacks at UC Berkeley dropped from 49.6\% in 1997 to $20.3 \%$ in 1998 , while over the same period the total number of applications by blacks to Berkeley actually increased from 1099 to 1164 . 
At UCLA, the admissions rate for blacks dropped from $38.4 \%$ in 1997 to $23.6 \%$ in 1998 while the total number of applications by black prospective students remained nearly flat at 1272 in 1997 and 1247 in 1998.

Figure 18 shows the black-white admissions rate gap for Berkeley and UCLA from 1994 to 2004. Prior to the implementation of Proposition 209, blacks were admitted at a higher rate than were whites; however, in 1998, the situation reversed itself dramatically and black admissions rates have remained behind those of whites ever since.

The percentage of total California resident admits who were black also dropped sharply in the fall of 1998 (Figure 19). In the years from 1994 to 1997, blacks comprised greater than seven percent of the total incoming freshman class at UC Berkeley, while in 1998, this fell to nearly three percent.

The proportion of the eighteen-year-old black population in California who applied and were admitted into Berkeley and UCLA for the years 1995 to 1999 are shown in Figures 20 and 21. There does appear to be a slight drop in 1997 application rates following the passage of Proposition 209 in 1996, although this appears to be small. The admissions rate per population, however, fell sharply in 1998, the first year in which the new law was binding for the entering fall cohort.

The impact at the University of Texas at Austin appears to be slightly different from that of the selective California schools. Figures 22 and 23 show the admissions rates by race/ethnicity and the blackwhite admissions gap for the years 1995 to 2004 at UT Austin. The admissions rates for blacks did decline towards the end of the twentieth century, but admissions rates for whites appear to have fallen slightly as well. The percentage black-white gap in admissions did jump in 1997, but this may be attributed to a drop in the total number of applications sent by blacks which fell from 809 in 1996 to 620 in 1997 and 596 in 1998 before starting to rise again to 957 in 1999.

The number of applications and admits as a proportion of the total eighteen-year-old black population in Texas for the years 1995 to 1999 are shown in Figures 24 and 25. Both the proportion of applications and admits for blacks dropped during the initial years following the policy change, but rebounded in 1999, particularly the application rate which rose above pre-Hopwood numbers by 1999. This is different than what was experienced in California during the same time period and is presumably due to the addition of the top-ten-percent plan implemented in Texas. 


\section{EMPIRICAL LITERATURE ON THE IMPACT OF ENDING AFFIRMATIVE ACTION}

While the descriptive picture discussed in the previous section paints a rather vivid portrait of the effects of ending affirmative action on application rates and admissions, particularly in California, it is important to note that these are merely descriptive statistics and do not control for a variety of factors that may also be contributing to the observed changes. Prior to 1996, it had been difficult for researchers in economics and other social sciences to assess the impact of affirmative action in university admissions because it was very difficult to isolate affirmative action from other societal factors that were occurring during the same time period. The gradual state-by-state erosion of affirmative action since 1996, however, has provided researchers with a plausible set of control groups - non-affected states - with which to analyze the end of affirmative action as a natural experiment. The last several years have seen a growing amount of literature within economics assessing the impact of the end of affirmative action in California, Texas, and Washington on the behavior of minorities within those states relative to minorities elsewhere over the same time period.

Mark Long examined the gap in SAT score reports sent by minority and non-minority students to in-state public colleges in California and Texas before and after the end of affirmative action. Using a ten percent random sample of SAT takers for the years 1996 to 2000 acquired from the College Board, Long used difference-in-difference-in-difference techniques to estimate if there was a significant change in minority SAT report behavior. Essentially, this technique compares a treatment group - in this case California and Texas minorities - to a set of control groups - minorities in other states and whites in California and Texasto test if the treatment group significantly altered their behavior as a result of the policy changes.

Controlling for gender, parental education, income, GPA, and SAT scores, Long finds that blacks and Hispanics in California significantly reduced the number of SAT score reports sent to in-state public colleges at all levels of college quality by about ten to fifteen percent. Texas showed negative but less significant results among blacks and Hispanics.

Brown and Hirschman used the passage of Initiative 200 in Washington State as a natural experiment to examine the effect on the transition from high school to college for minority students in Washington. They find that the proportion of minority high school students making the transition to college declined temporarily following the end of affirmative action. They examine the number of applications 
for minority students and conclude that the observed declines were more the result of drops in application rates rather than admissions rates. They also find that nearly all of the declines occurred at the University of Washington, which is the most selective of the six four-year public universities and colleges in the state of Washington.

Dickson examined the impact of the Hopwood decision on the percent of minority students applying to college from Texas. Using data from the Texas Education Agency, Dickson estimated the impact of the ending of affirmative action and subsequent adoption of the ten-percent plan on the decision of minority students to take college admissions tests. Using weighted fixed effects estimation and controlling for a variety of factors, the author finds that the ending of affirmative action caused a significant decline in the number of Hispanic students applying to college by $1.6 \%$ and a significant drop in the number of black students applying to college by $2.1 \%$. These initial declines, however, were mitigated somewhat by the implementation of the ten-percent plan and accompanying changes in financial aid.

Card and Krueger found slightly different results regarding minority application patterns when focusing on highly qualified minority students. Highly qualified students are defined as minority students who meet entrance requirements regardless of affirmative action policies and therefore should not be directly affected by the policy changes. Using data derived from the College Board's Test Takers Data Base, and controlling for race/ethnicity, year, SAT scores, and GPA, they find no significant changes in SAT sending behavior among highly qualified blacks or Hispanics in either California or Texas following the end of affirmative action.

\section{VII.THE IMPACT OF ENDING AFFIRMATIVE ACTION ON THE HUMAN CAPITAL DEVELOPMENT OF YOUNGER CHILDREN}

Caldwell hypothesizes that the ending of affirmative action in university admissions may impact the human capital investment decisions of younger minority children by reducing the perceived opportunities to attend college and therefore reducing the expected net rate of return to human capital investment. To test the hypothesis, the author examines the effect of the policy changes in California and Texas on cognitive test scores for children in those states following the end of affirmative action.

The empirical analysis was done using data from the National Longitudinal Survey of Youth 1979 cohort (NLSY79) and the children of the NLSY79 survey (CNLSY79). The NLSY79 is a nationally- 
representative sample of 12,686 men and women who were between the ages of fourteen and twenty-one as of January 1, 1979. Interviews for the NLSY79 have been conducted annually from 1979 to 1994 and biannually since 1994. The CNLSY79, initiated in 1986, consists of all children born to NLSY79 mothers. As of 2002, the sample has included 10,466 children between the ages of one and fourteen born to 4523 mothers. The benefits of these data are that they provide a rich set of background variables for both the mothers and children, and the same individuals are continuously surveyed throughout the entire period of interest.

The cognitive assessment measure used in the analysis is the Peabody Individual Achievement Test (PIAT) for Mathematics. This assessment test was repeatedly administered to all children in the sample between the ages of five and fourteen during each wave of the survey. The PIAT math test consists of eighty-four multiple-choice questions of increasing difficulty, beginning with elementary arithmetic and progressing to advanced concepts in geometry and trigonometry.

Estimation was done using two methods. First, the data were organized into independent cross-sections broken down by age group. These data were then analyzed using both difference-in-difference and difference-in-difference-in-difference methodologies. The purpose of using this methodology is to control for unobservable characteristics or events that may be affecting both groups over time that would otherwise lead to biased results. The cross-sectional analysis compared test scores for groups of children of similar ages before and after the policy changes. Second, the data were arranged as a panel and the same individuals were analyzed over time using an individual fixed-effects model to determine if there was a resulting change in the rate of growth in test scores as children aged.

A highly significant, negative impact was found for black children in the affected states (California and Texas) relative to whites in those states and children of all races and ethnicities in unaffected states. The results were very robust for all model specifications, and included controls for gender, grade, age, mother's education, birth order, and whether the child lived in an urban area.

Figures 26-29 show the estimated distribution of test scores for various groups. Figure 26 compares the distribution of test scores for thirteen- and fourteen-year-old blacks in California and Texas both before and after the policy changes occurred. There is an apparent shift to the left for nearly the entire distribution, showing that test scores within the data dropped significantly after the policy changes occurred in California and Texas. As a means of comparison, Figure 27 shows the 
distribution of test scores for thirteen- and fourteen-year-old blacks living in states other than California and Texas before and after 1997. This was the control group, and showed virtually no change in the distribution of test scores over time. This suggests that the large drop that was observed in Figure 26 was not part of a national shift but was isolated to California and Texas, providing evidence that the affirmative action policy changes may have played a role.

Figures 28 and 29 compare thirteen- and fourteen-year-old blacks and whites in California and Texas before the policy changes and after. The gap that is evident in Figure 28 is the well-known test-score gap that exists between blacks and whites. Figure 29 shows this gap to grow much larger after the policy changes.

Figures 30 and 31 show the distribution of growth in test scores as children age from a period prior to the policy changes to a period after the policy changes. Again, we observe a significantly slower rate of growth among black children relative to whites in California and Texas (Figure 30), and between blacks in California and Texas and blacks elsewhere (Figure 31).

\section{VIII.DISCUSSION}

It is well-established that blacks receive substantially lower median earnings, have higher rates of unemployment, and have lower levels of labor force attachment than do whites. Much of this can likely be attributed to lower levels of educational attainment. Recent data on educational attainment and median annual earnings, unemployment rates, and labor force participation rates suggests that blacks disproportionately benefit from greater levels of educational attainment relative to other races. Policies, therefore, that promote greater involvement among blacks in institutions of higher education may prove very beneficial in bridging portions of the current black white earnings gap.

Over the past forty years there have been substantial gains in the proportion of blacks receiving four-year degrees. In relative terms, however, the black-white education gap remains as wide now as it was in 1974, suggesting that the use of affirmative action may not have had the impact that many had hoped it would when it was implemented. The removal of affirmative action, however, appears to have been very harmful for minorities, particularly in California, where the largest drop in application and admissions rates occurred. Perhaps most disturbing is the apparent effect that it has had on younger children, resulting in lower test scores and lower levels of overall human capital investment. 
Although the use of affirmative action in university admissions may not have had the full intended impact of bridging the educational attainment gap and helping to bring us closer to economic equality, its removal appears to be heading us back in the other direction. The shortterm efficiency gains that can be had by removing affirmative action and admitting the most highly-qualified applicants regardless of race should be carefully weighed against the long-term benefits of continuing on with the program.

\section{REFERENCES}

R. Michael Alvarez \& Lisa García Bedolla, The Revolution Against Affirmative Action in California: Racism, Economics, and Proposition 209, 4 ST. POL. \& POL'Y Q. 1 (2004).

Valentina A. Bali \& R. Michael Alvarez, Schools and Educational Outcomes: What Causes the "Race Gap" in Student Test Scores?, 84 SoC. SCI. Q. 485 (2003).

Susan K. Brown \& Charles Hirschman, The End of Affirmative Action in Washington State and Its Impact on the Transition from High School to College, 79 Soc. EDUC. 106 (2006).

Ronald Caldwell, The Effects of University Affirmative Action Policies on the Human Capital Development of Minority Children: Do Expectations Matter? (Univ. of Kan. Dep't of Econ., Working Paper No. 200812, 2008).

David Card \& Alan Krueger, Would the Elimination of Affirmative Action Affect Highly Qualified Minority Applicants? Evidence from California and Texas, 58 INDUS. \& LAB. REL. REV. 416 (2004).

Pedro Carneiro, James J. Heckman \& Dimitry V. Masterov, Labor Market Discrimination and Racial Differences in Premarket Factors, 48 J. L. \& ECON. 1 (2005).

Lisa M. Dickson, Does Ending Affirmative Action in College Admissions Lower the Percent of Minority Students Applying to College?, 25 ECON. EDUC. REV. 109 (2006).

Roland G. Fryer, Jr. \& Steven D. Levitt, Understanding the BlackWhite Test Score Gap in the First Two Years of School, 86 REV. ECON. \& STAT. 447 (2004).

Roland G. Fryer, Jr. \& Steven D. Levitt, The Black-White Test Score Gap Through Third Grade, 8 AM. L. \& ECON. REV. 249 (2006).

Harry J. Holzer \& David Neumark, What Does Affirmative Action Do?, 53 INDUS. \& LAB. REL. REV. 240 (2000). 
Christopher Jencks \& Meredith Phillips, The Black-White Test Score Gap: An Introduction, in THE BLACK-WHITE TEST SCORE GAP 1 (Christopher Jencks \& Meredith Phillips eds., 1998).

Thomas J. Kane, Racial and Ethnic Preferences in College Admissions, in THE BLACK-WHITE TEST SCORE GAP 431 (Christopher Jencks \& Meredith Phillips eds., 1998).

Mark C. Long, College Applications and the Effect of Affirmative Action, 121 J. ECONOMETRICS 319, (2004).

Mark C. Long, Race and College Admissions: An Alternative to Affirmative Action?, 86 REV. ECON. \& STAT. 1020 (2004).

Mark C. Long, Affirmative Action and Its Alternatives in Public Universities: What Do We Know?, 67 PUB. AdMIN. REV. 315 (2007).

Meredith Phillips et al., Family Background, Parenting Practices, and the Black-White Test Score Gap, in THE BLACK-WHITE TEST SCORE GAP 103 (Christopher Jencks \& Meredith Phillips eds., 1998).

Figure 1: 2005 Educational Attainment by Race/EthnicityUS Population Age 25+

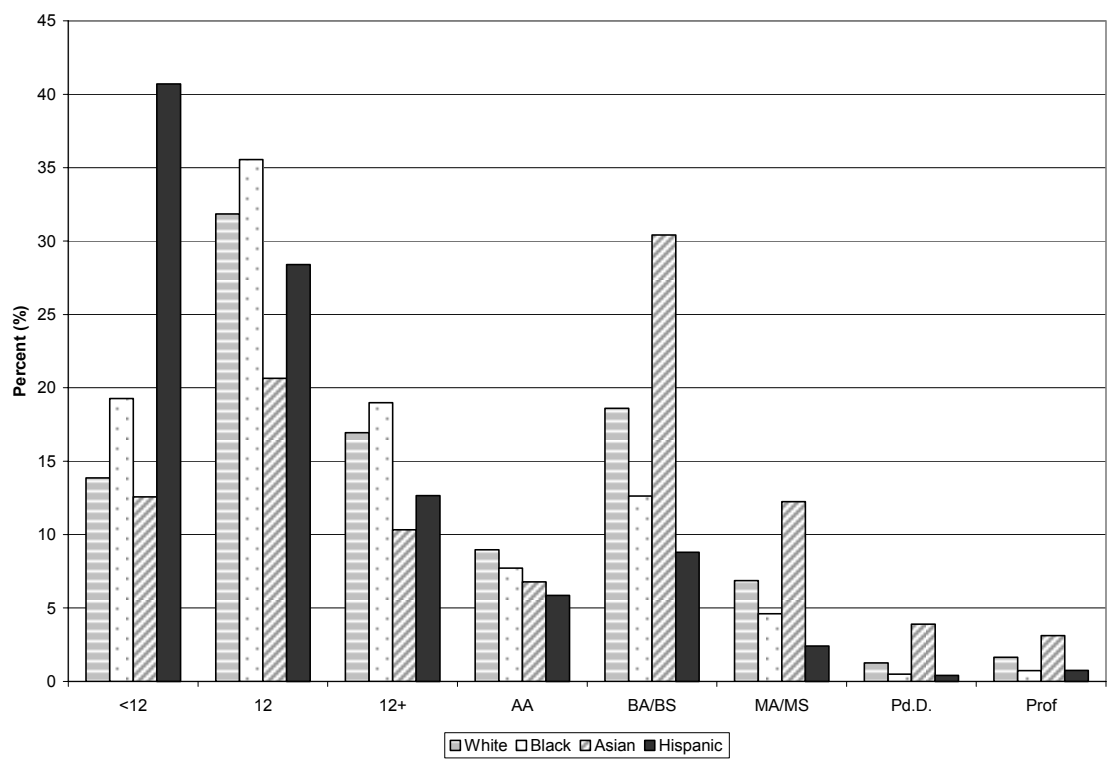

Source: U.S. Census Bureau 
Figure 2: Percent of Population Completing

Four Years of College or More-Ages 25 to 29

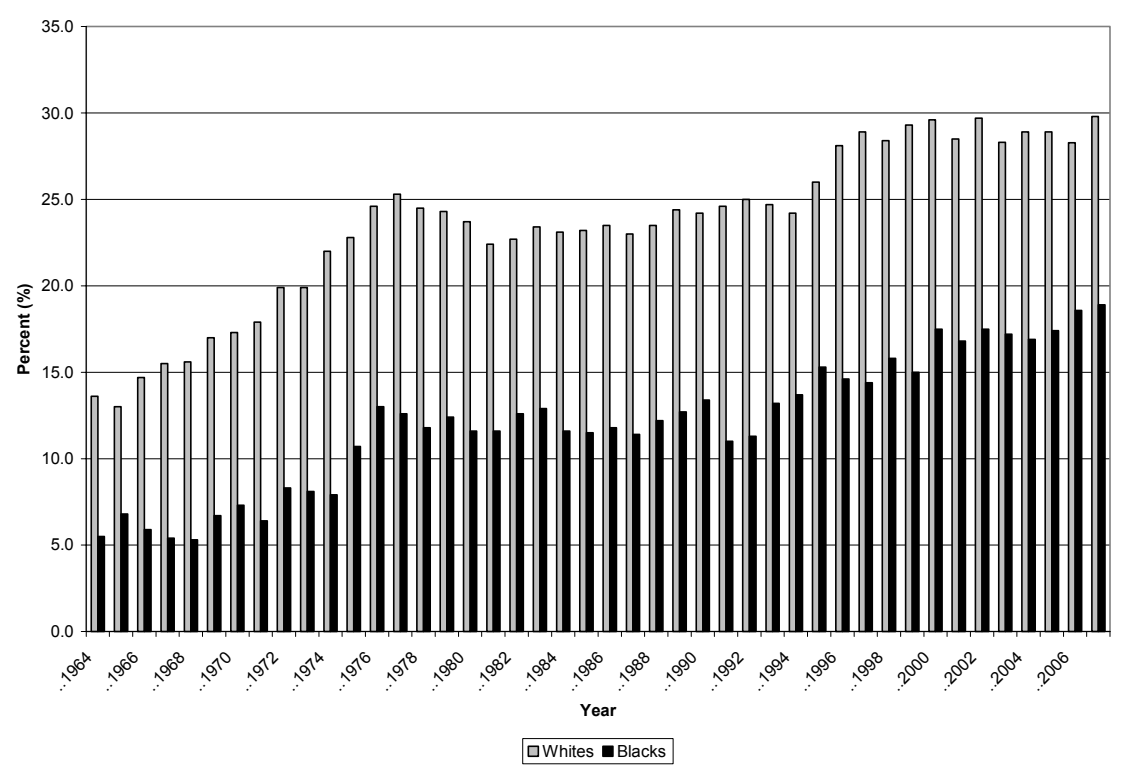

Source: U.S. Census Bureau

Figure 3: Black-White Gap in Percent of Population with Four Years of College or More-Ages 25 to 29

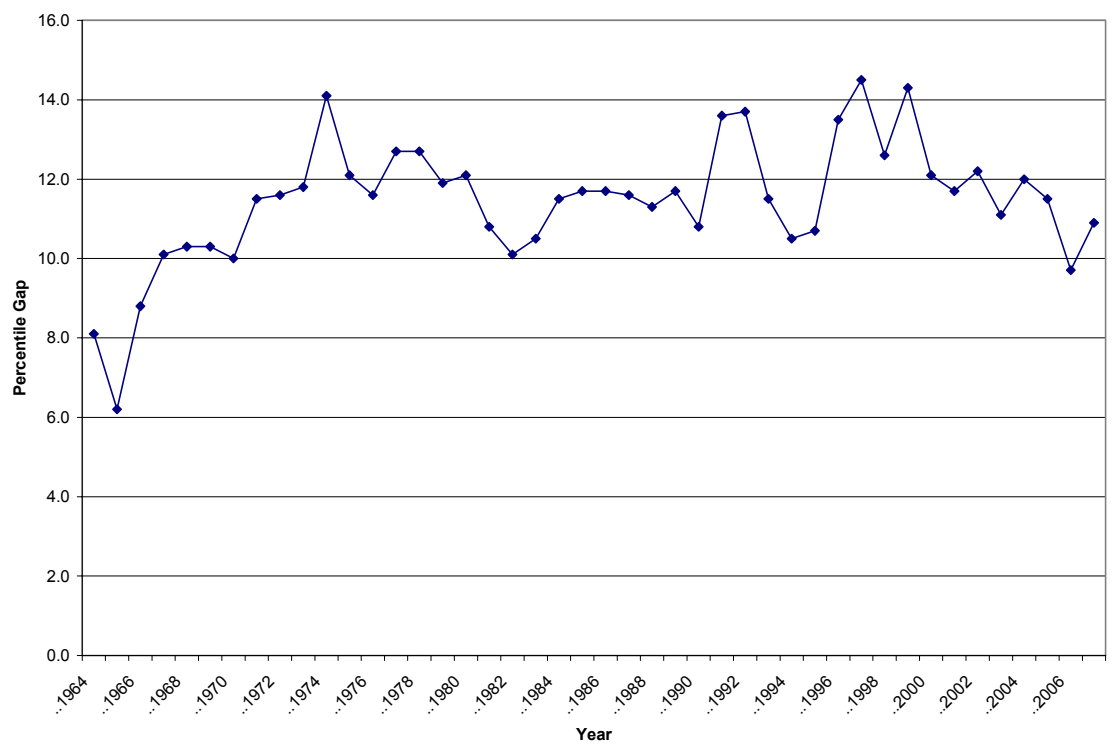


Figure 4: 2005 Median Earnings All Workers Age 25+

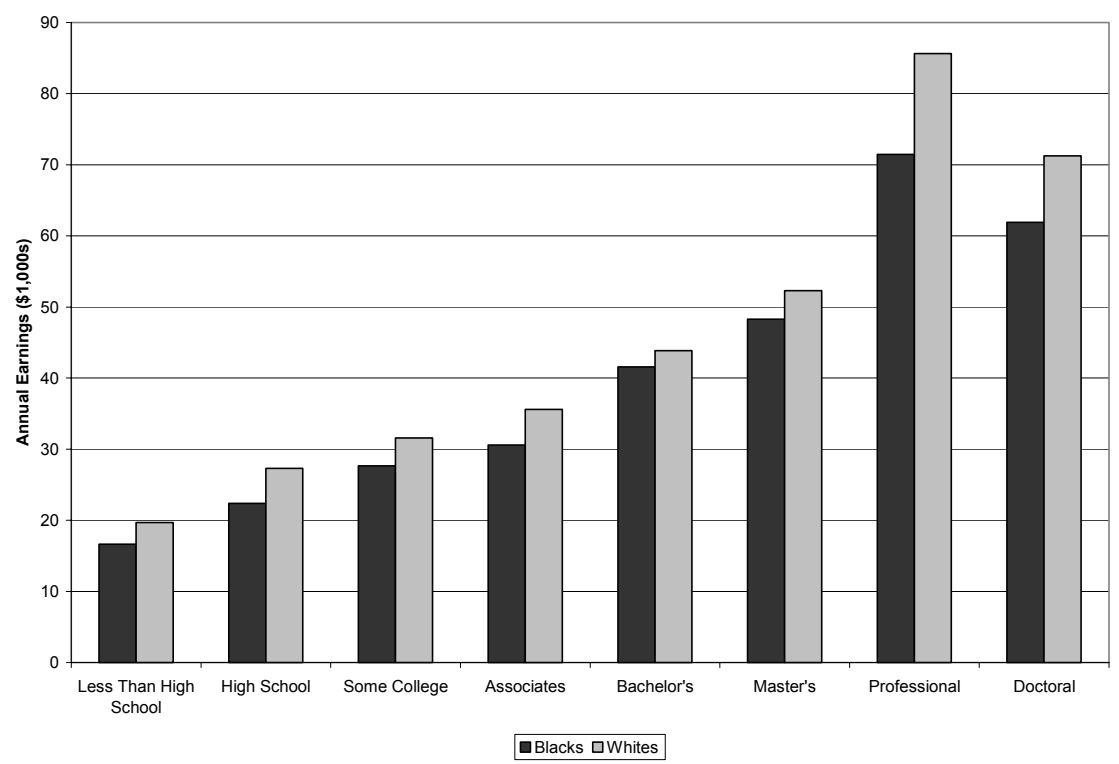

Source: U.S. Census Bureau

Figure 5: Annual Unemployment Rate-Ages 25+

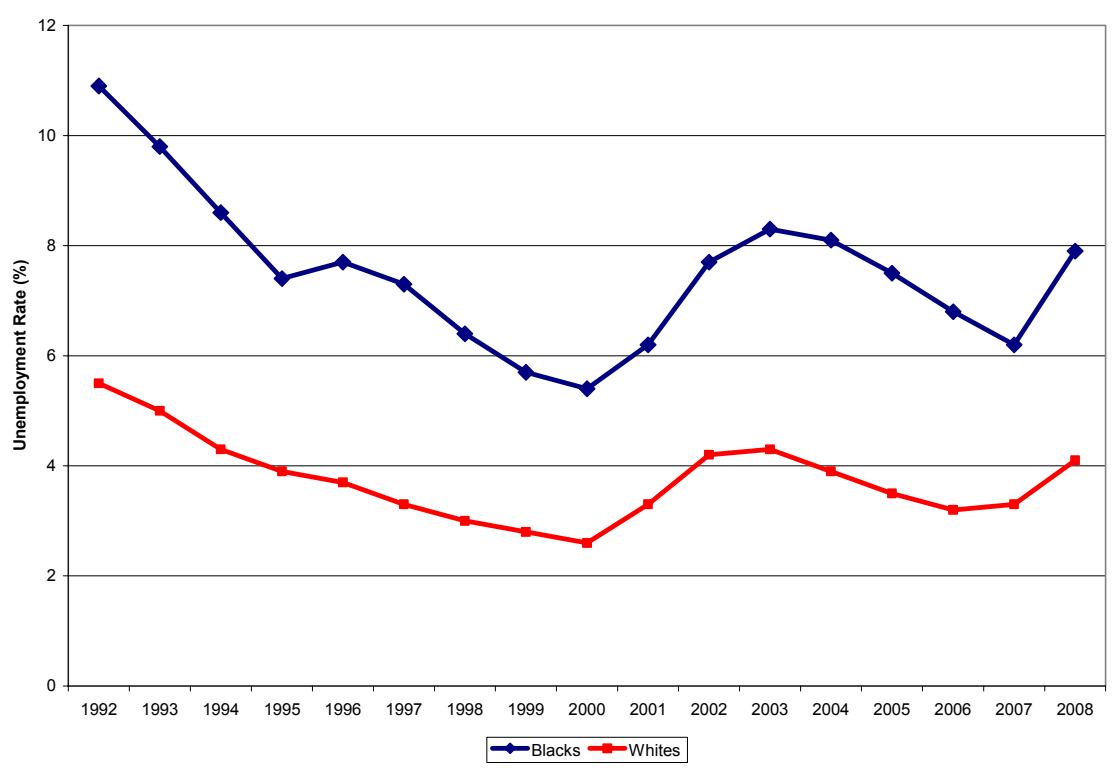

Source: Bureau of Labor Statistics 
Figure 6: Annual Unemployment Rates by Education Level-Ages 25+

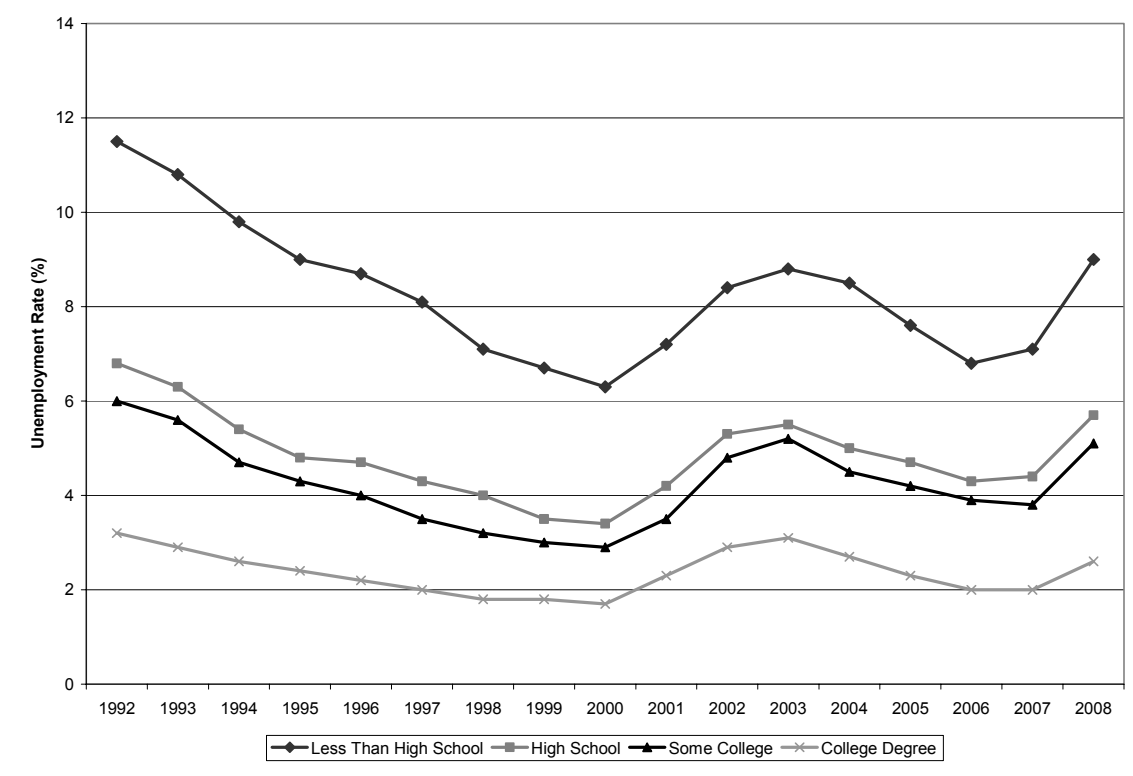

Source: Bureau of Labor Statistics

Figure 7: Unemployment Rate by Education Level and Race/Ethnicity_-Ages 25+

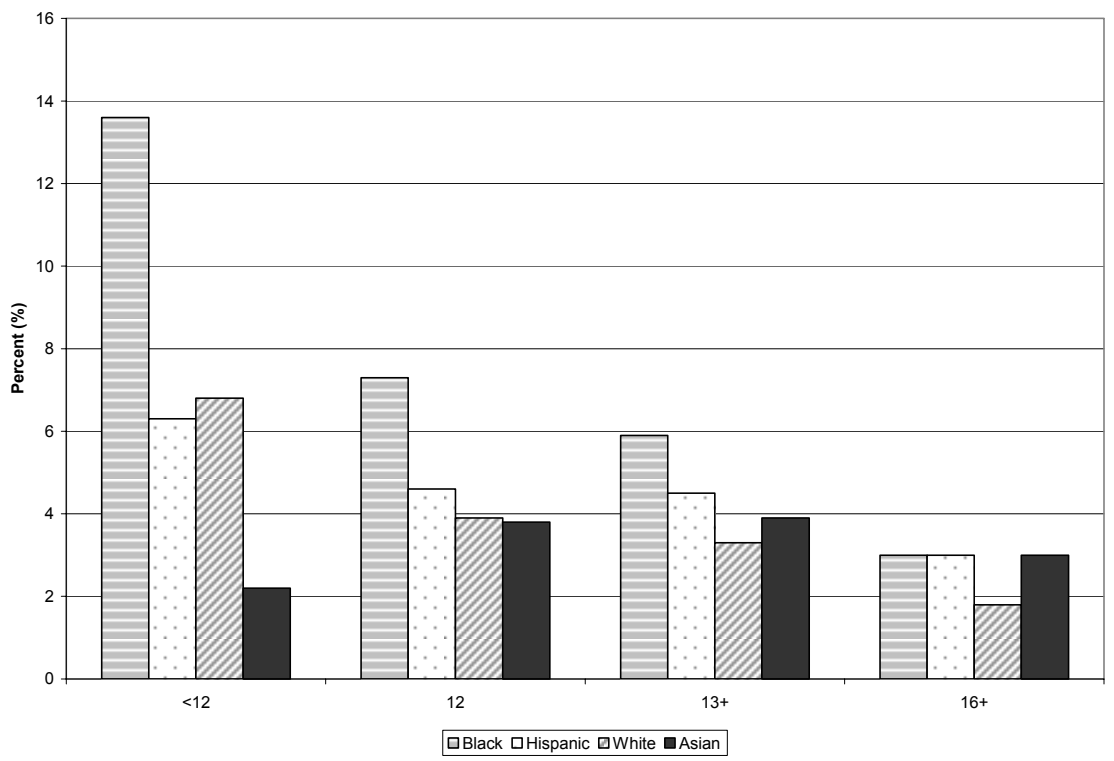

Source: Bureau of Labor Statistics 
Figure 8: Annual Labor Force Participation Rates by Education Level-Ages 25+

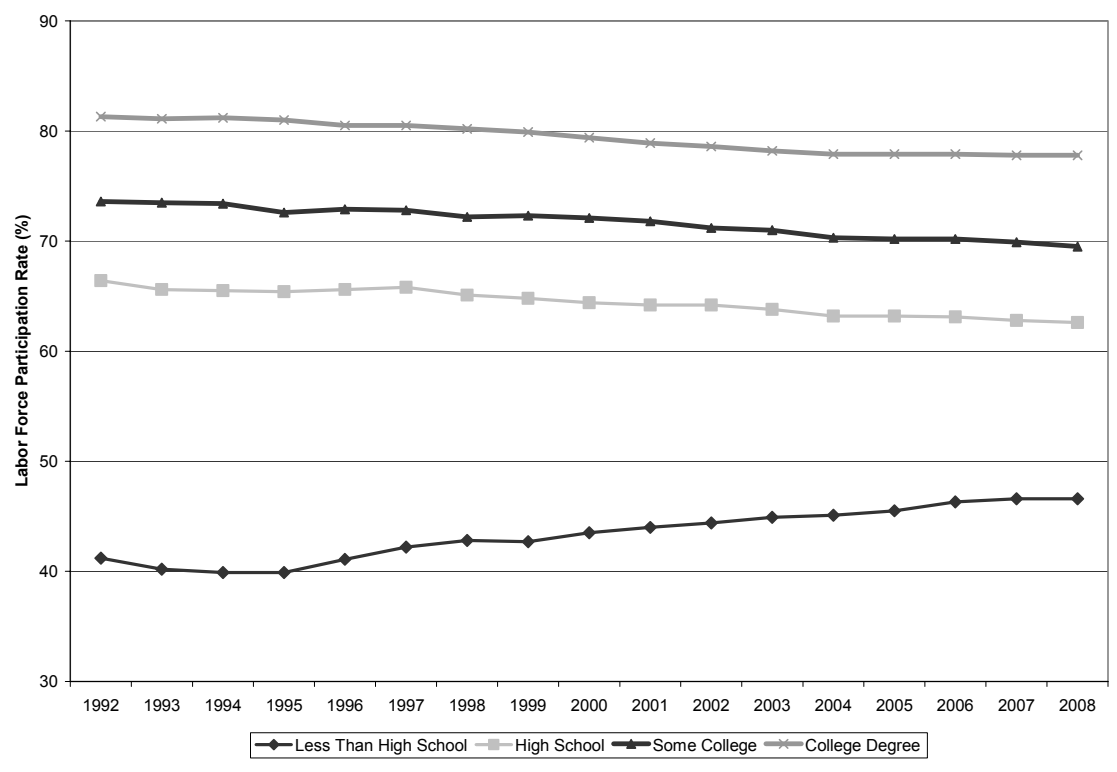

Source: Bureau of Labor Statistics

Figure 9: Labor Force Participation Rate-Seventeen Year Average (1992-2008)-Ages 25+

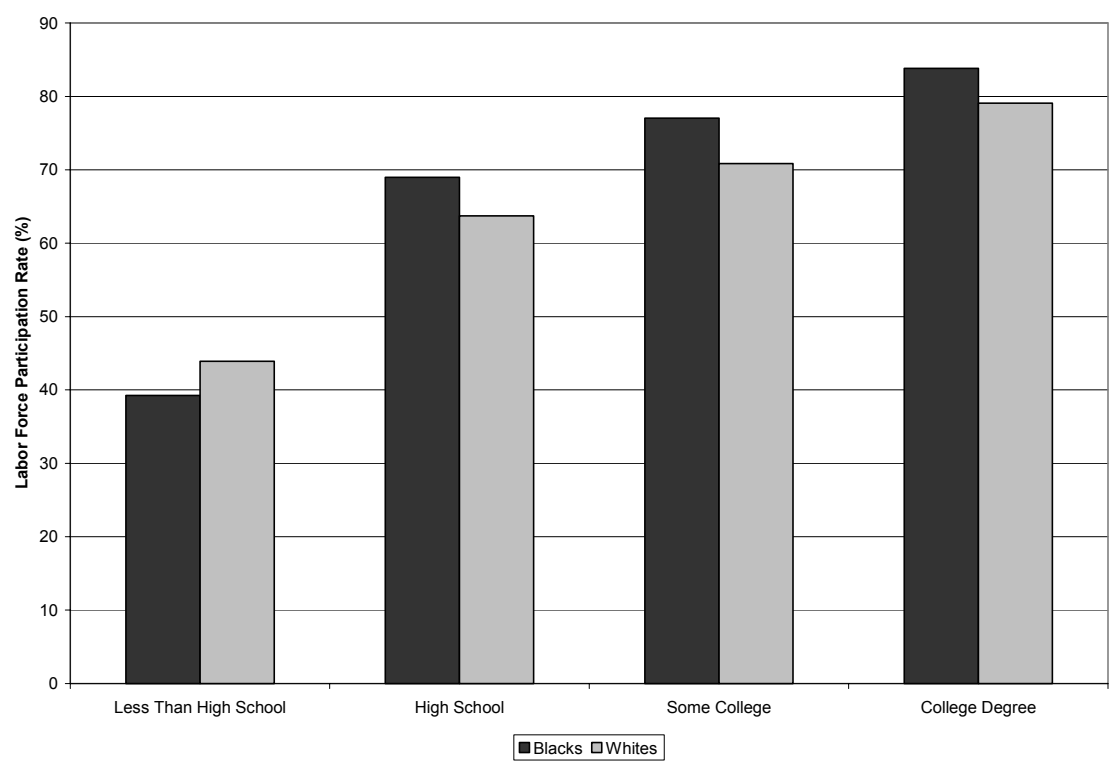

Source: Bureau of Labor Statistics 
Figure 10: Admit Rates_-University of California System

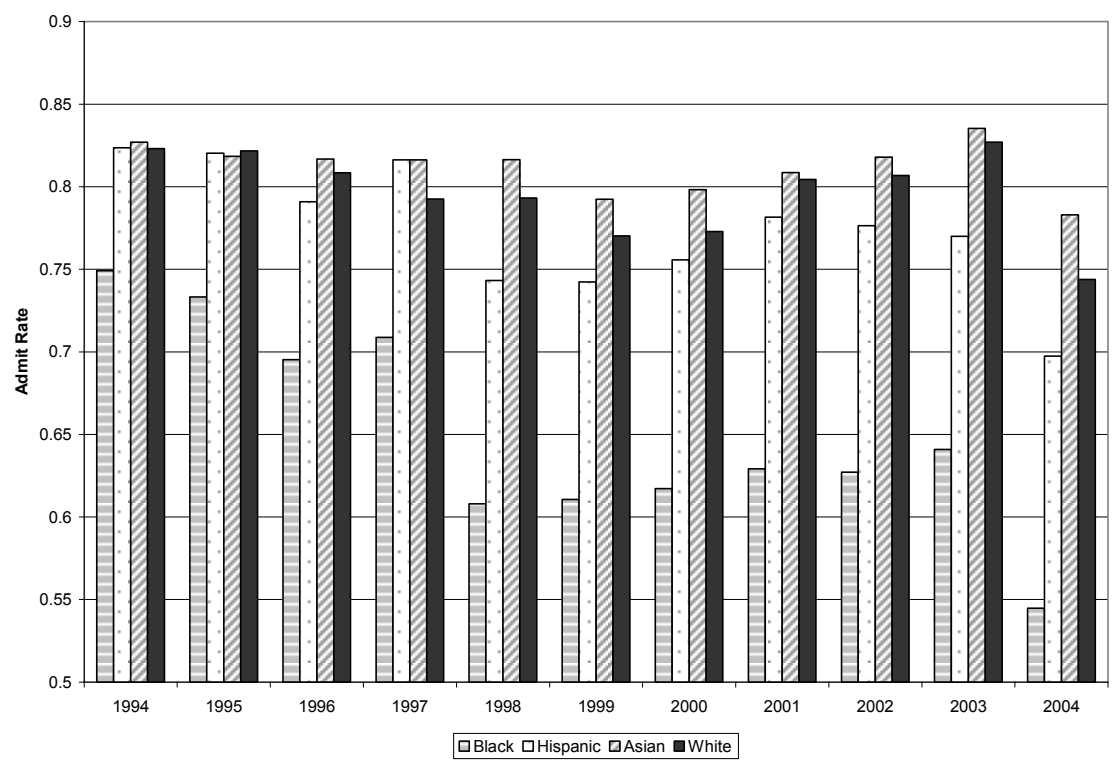

Source: University of California StatFinder

Figure 11: University of California System Black-White Admissions Gap

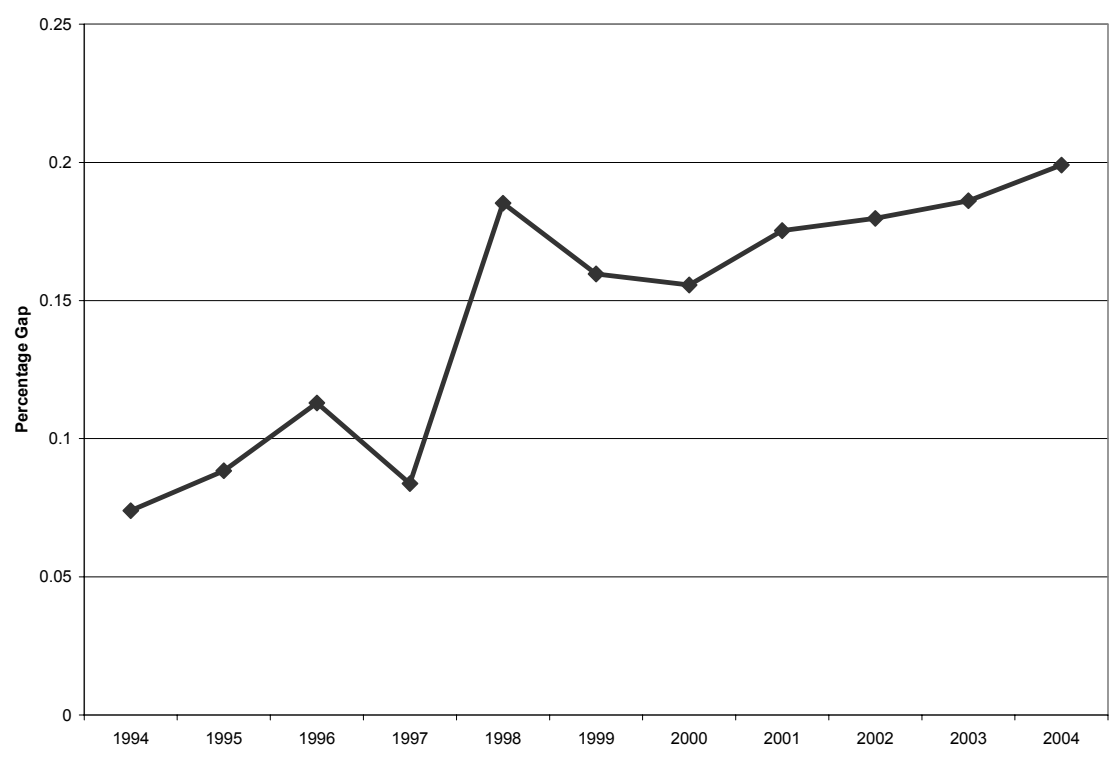


Figure 12: University of California System Black Admits as

Percent of Total Admits

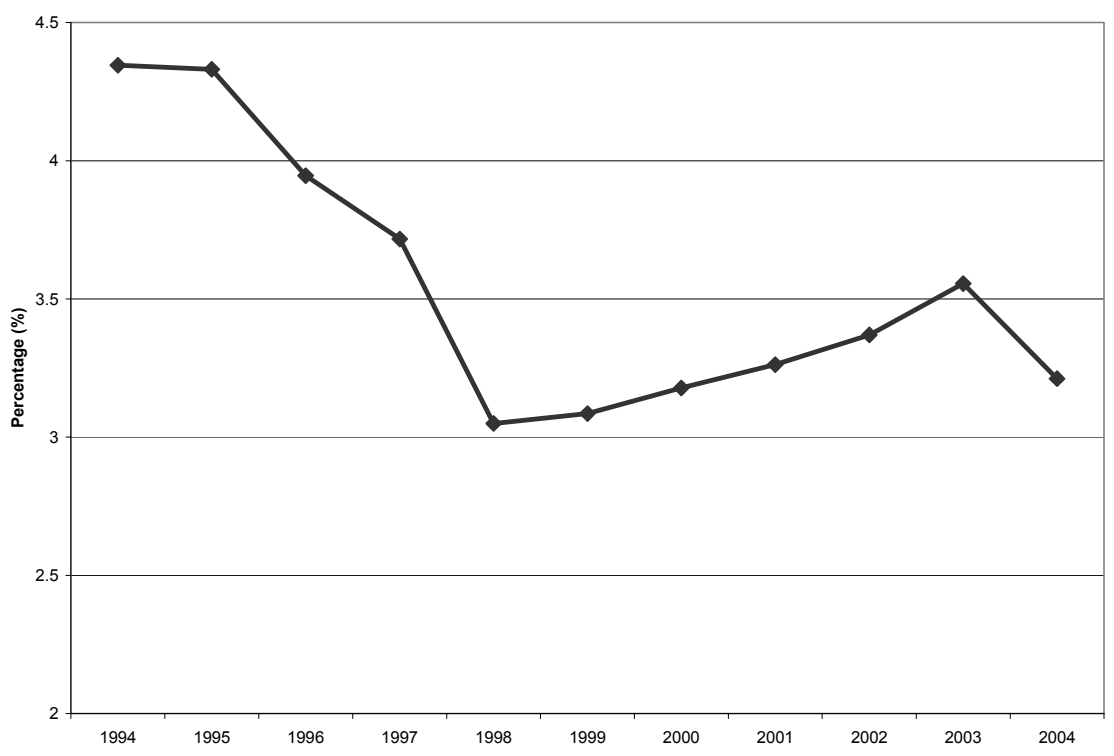

Figure 13: UC System Black Application Rates as a Percent of Total 18-Year-Old Black Population in California

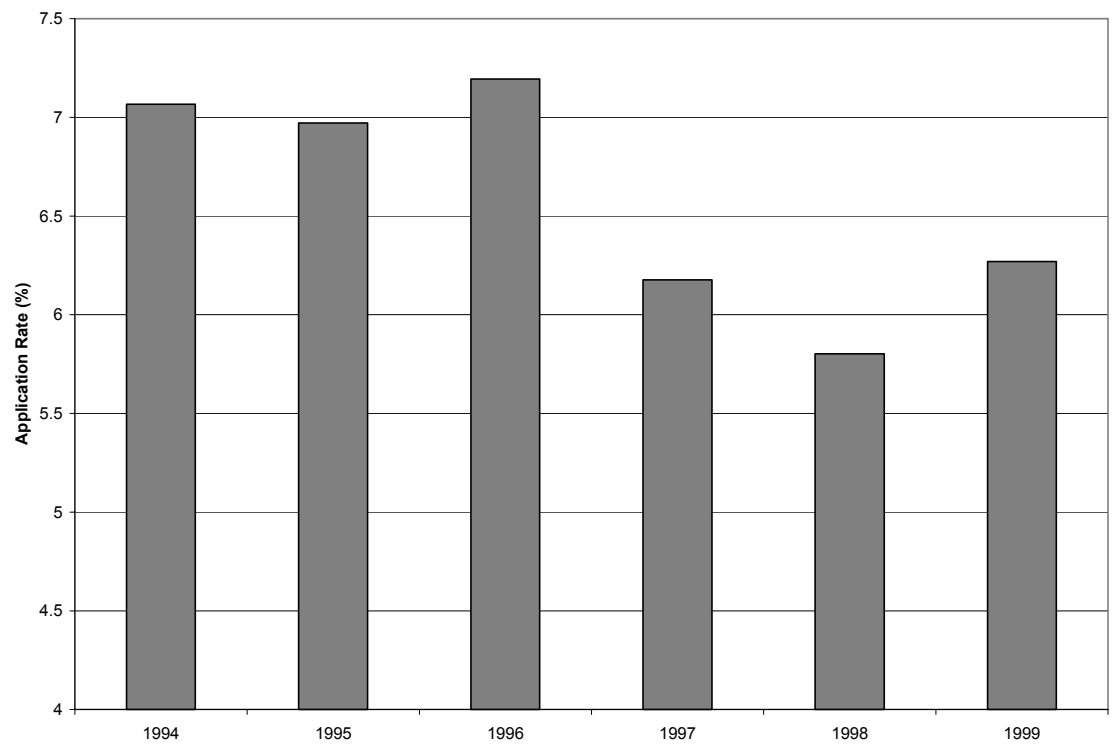


Figure 14: UC System Black Admit Rates as a Percent of Total 18-Year-Old Black Population in California

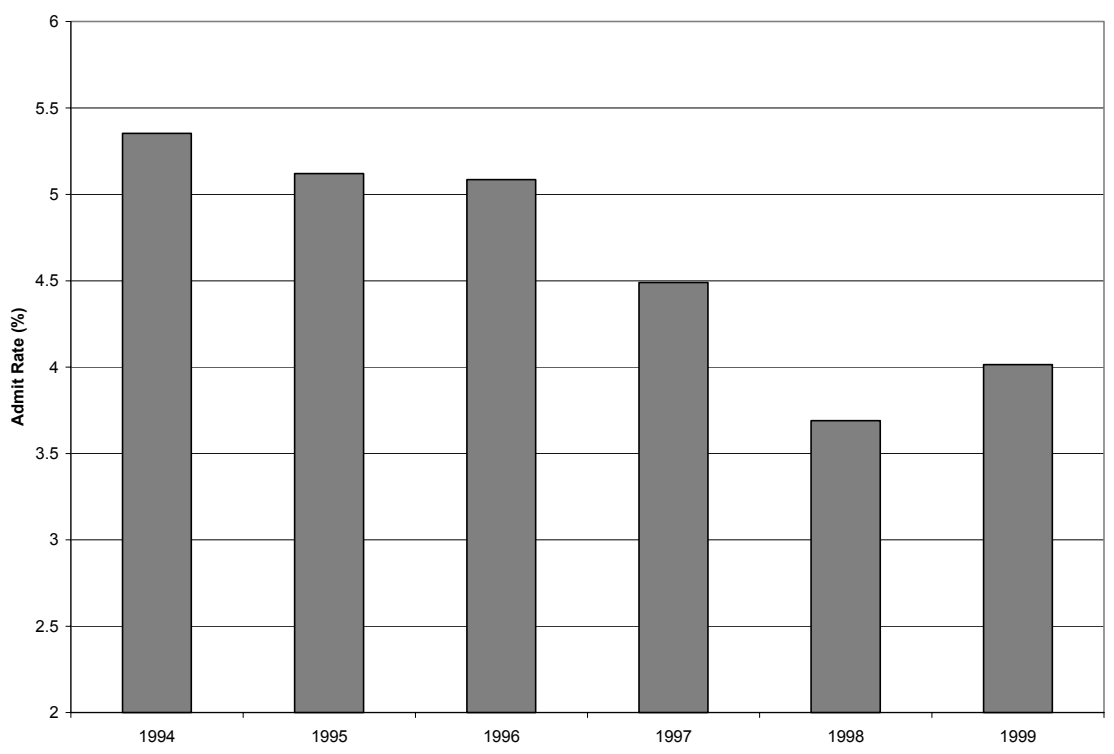

Figure 15: Admissions Rate-UC Berkeley

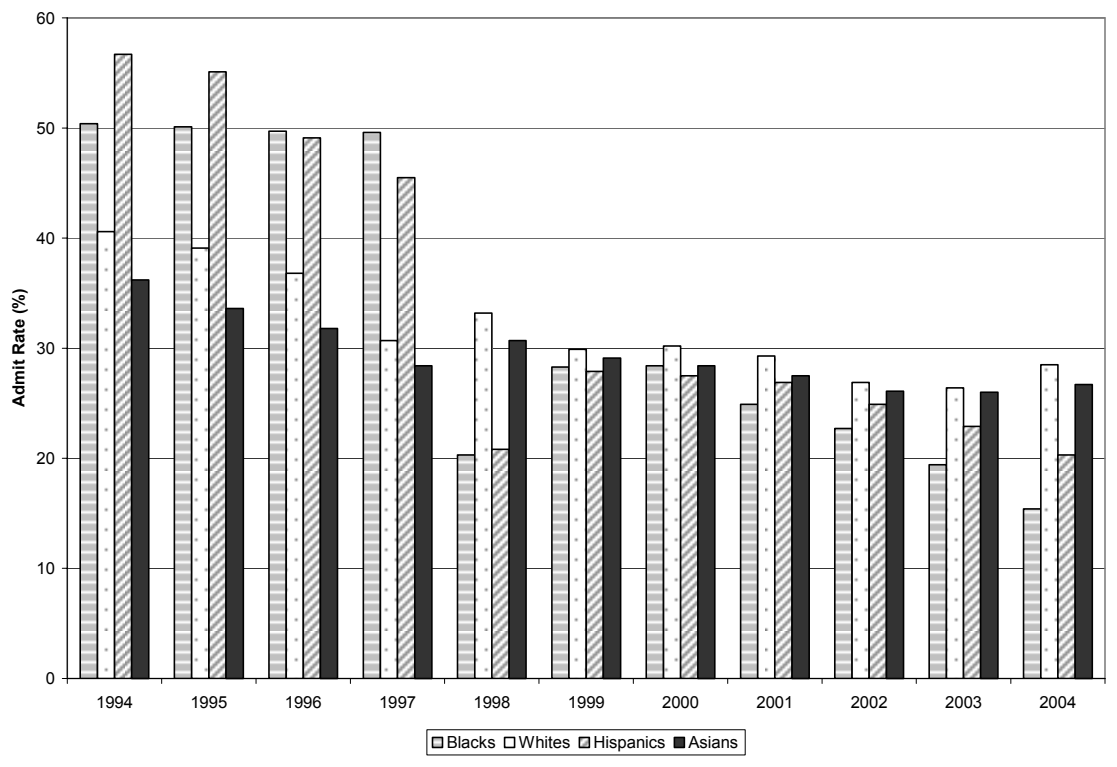


Figure 16: Admissions Rate-UCLA

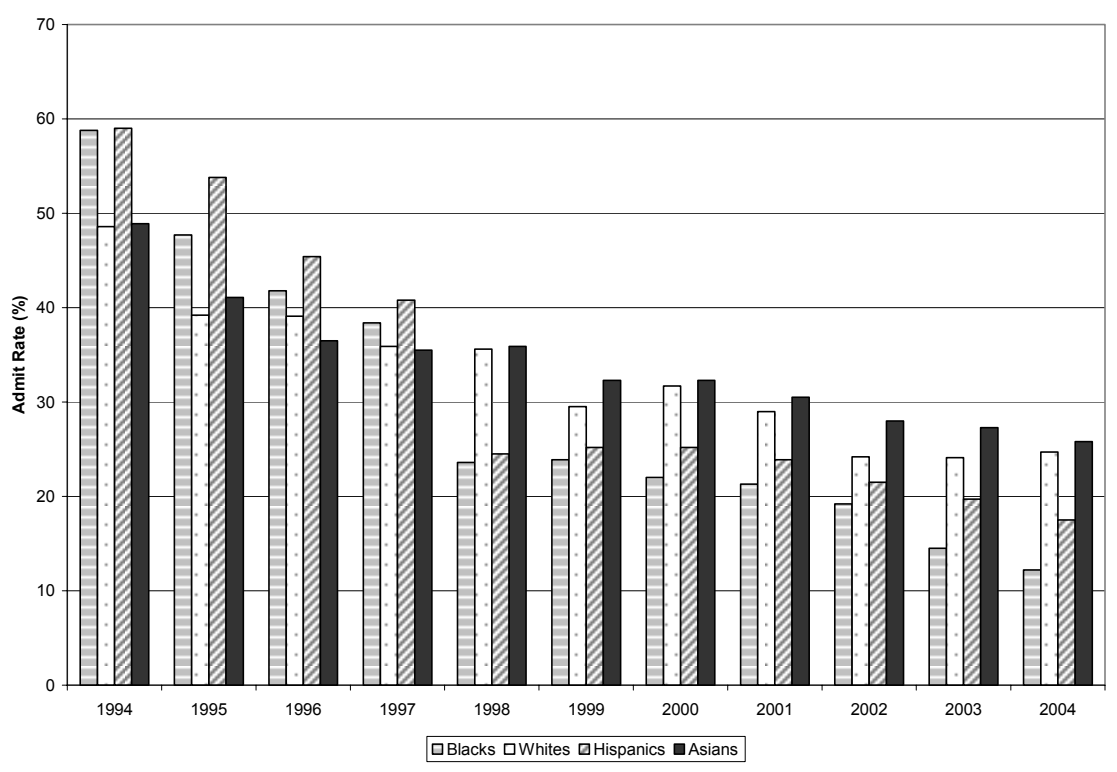

Figure 17: Admissions Rate-Blacks

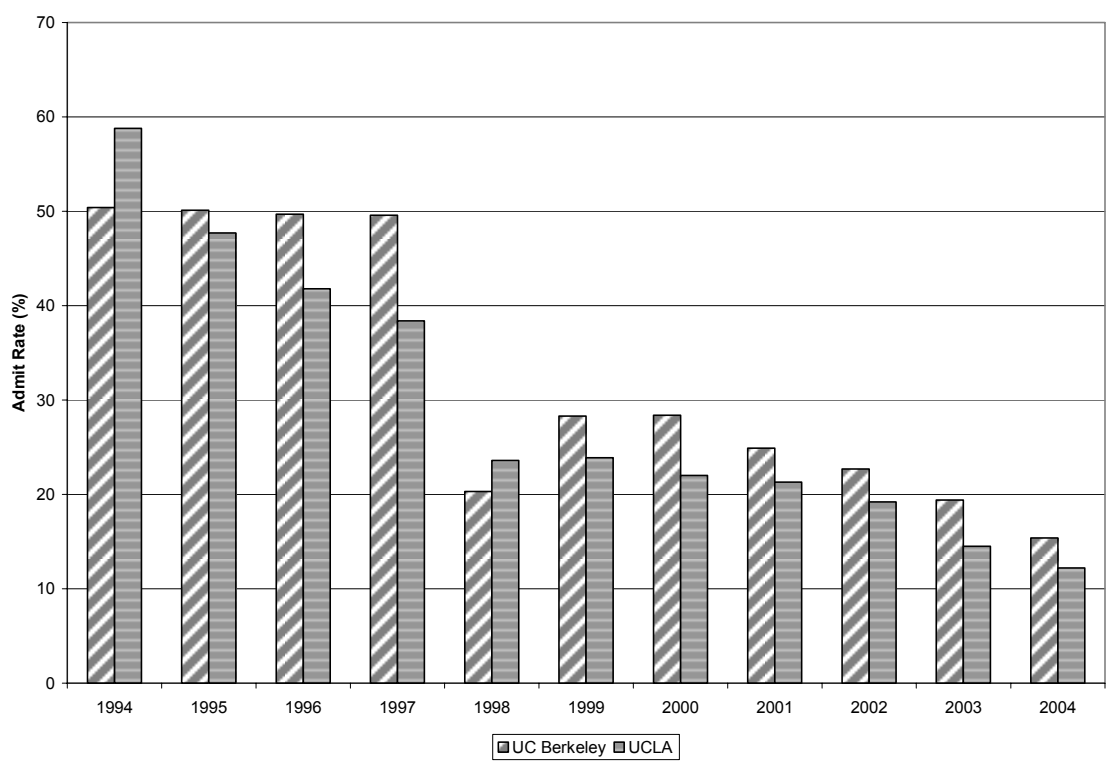


Figure 18: Black-White Admissions Gap

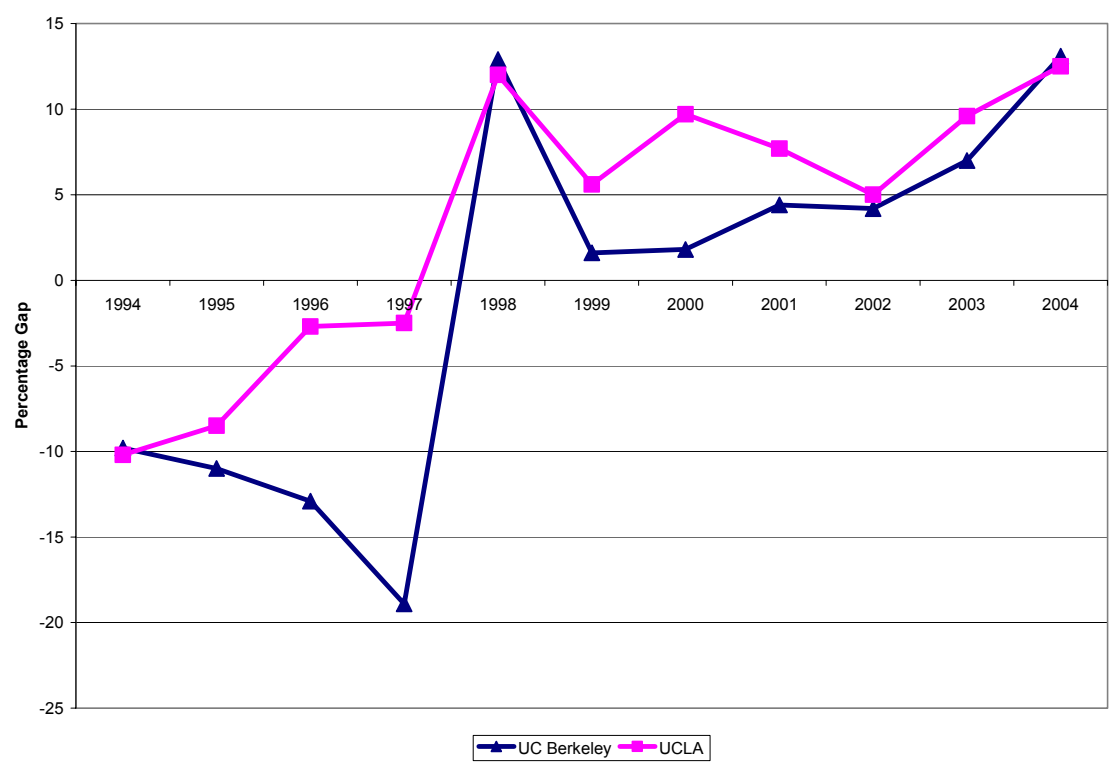

Figure 19: Black Admits as Percent of Total Admits

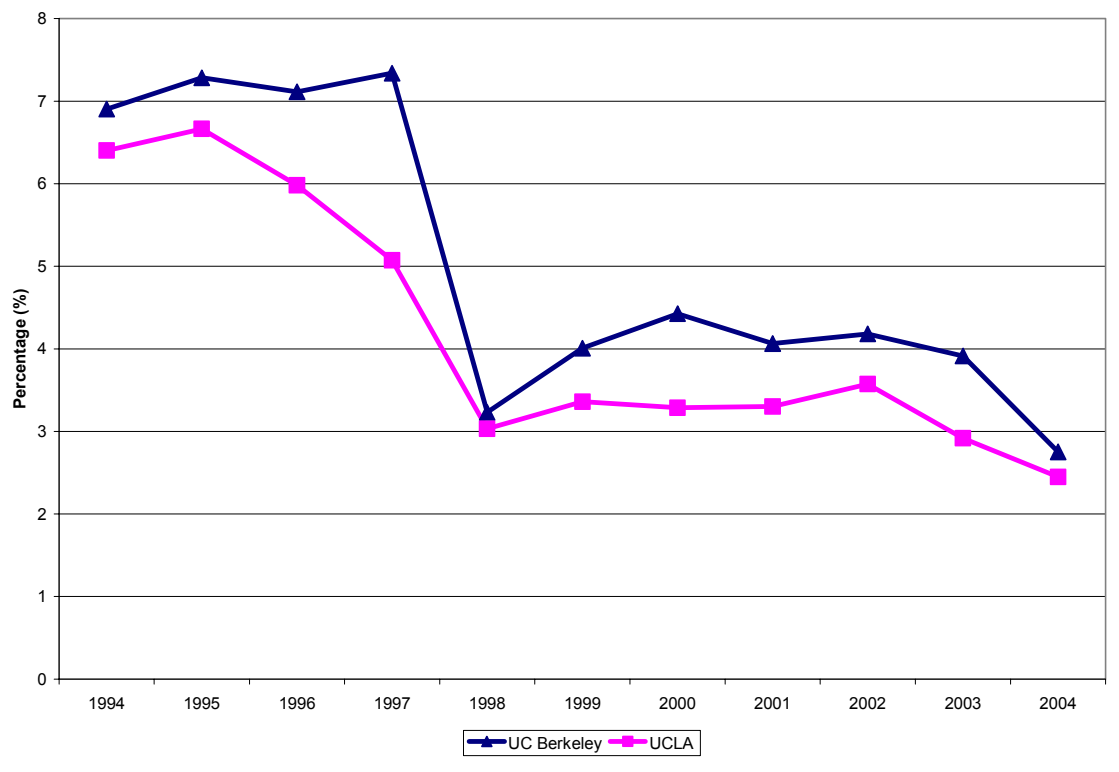


Figure 20: Black Application Rates as a Percent of Total 18-Year-Old Black Population in California

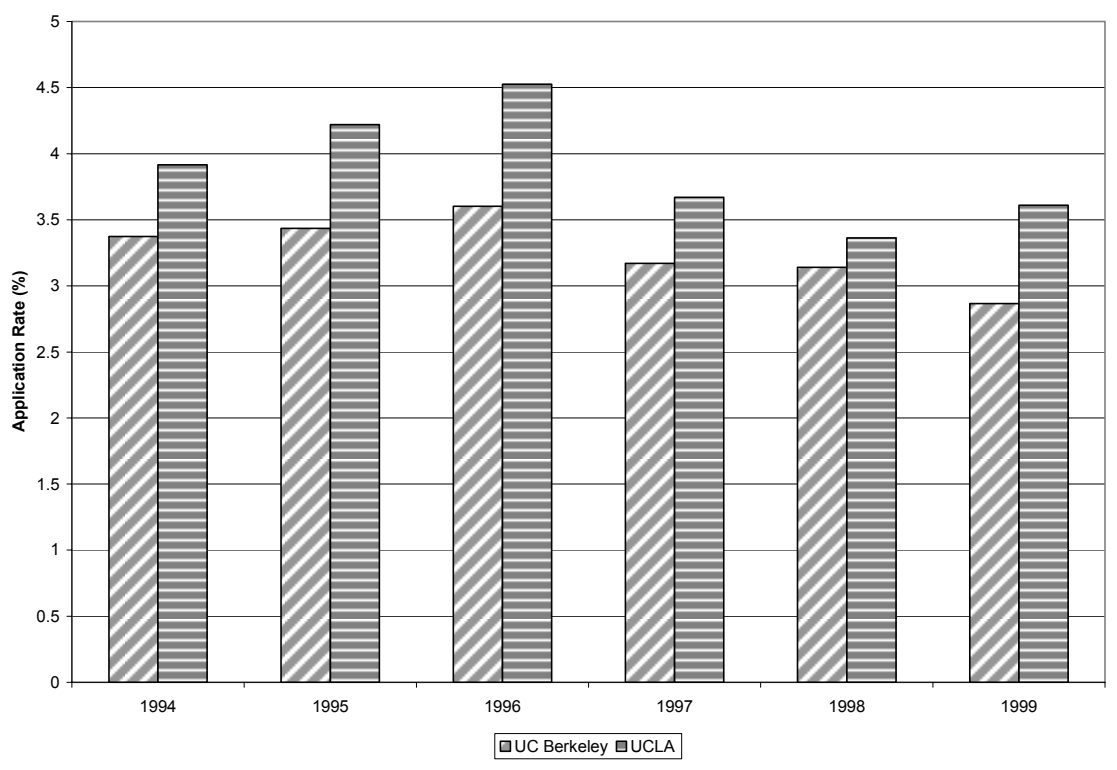

Figure 21: Black Admit Rates as a Percent of Total 18-Year-Old Black Population in California

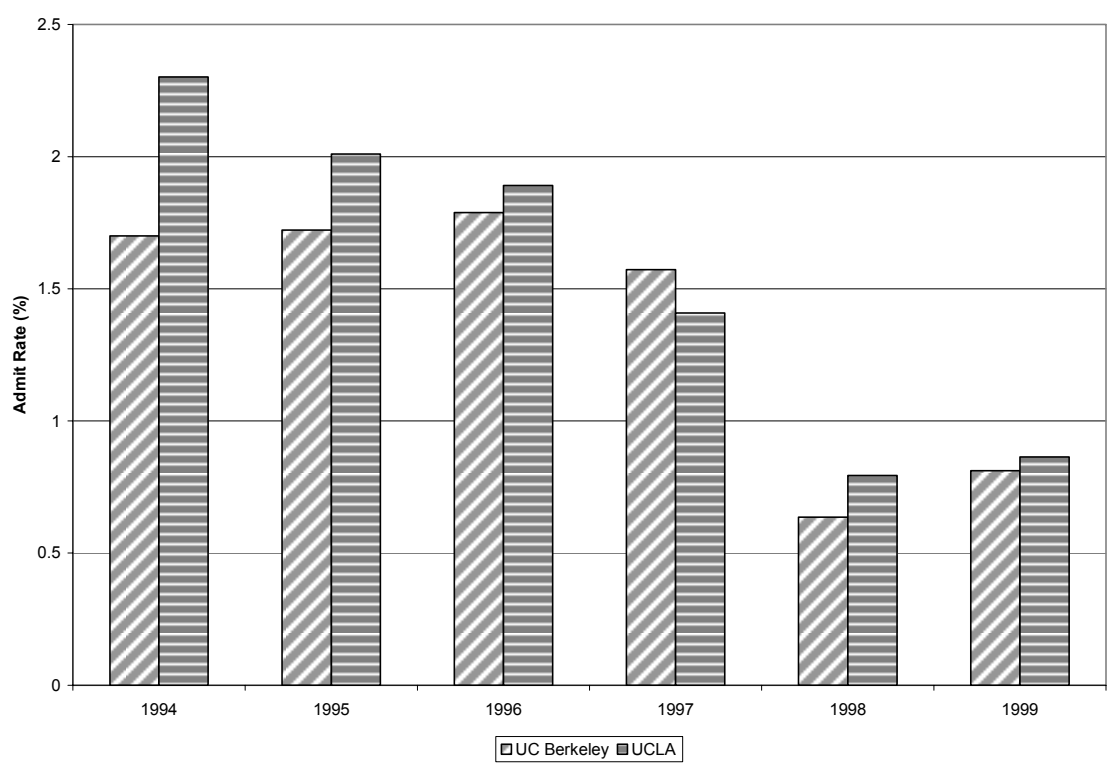


Figure 22: Admit Rates-University of Texas Austin

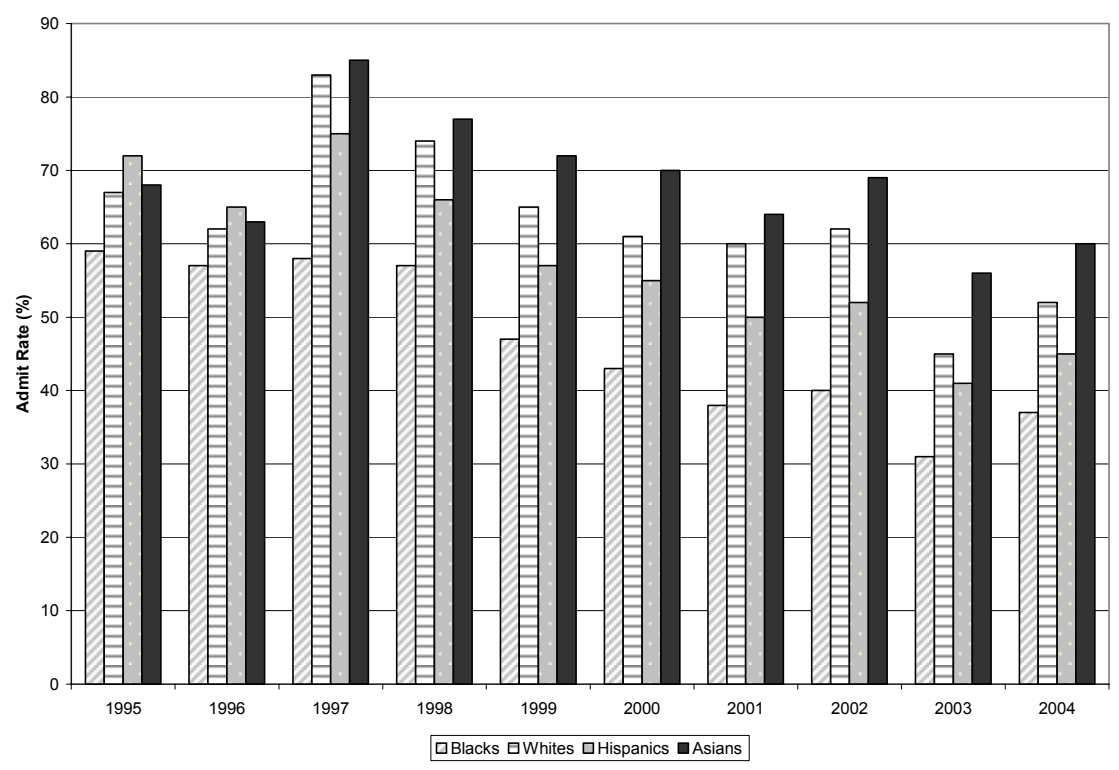

Source: UT Austin Office of Institutional Research

Figure 23: UT Austin Black-White Admissions Gap

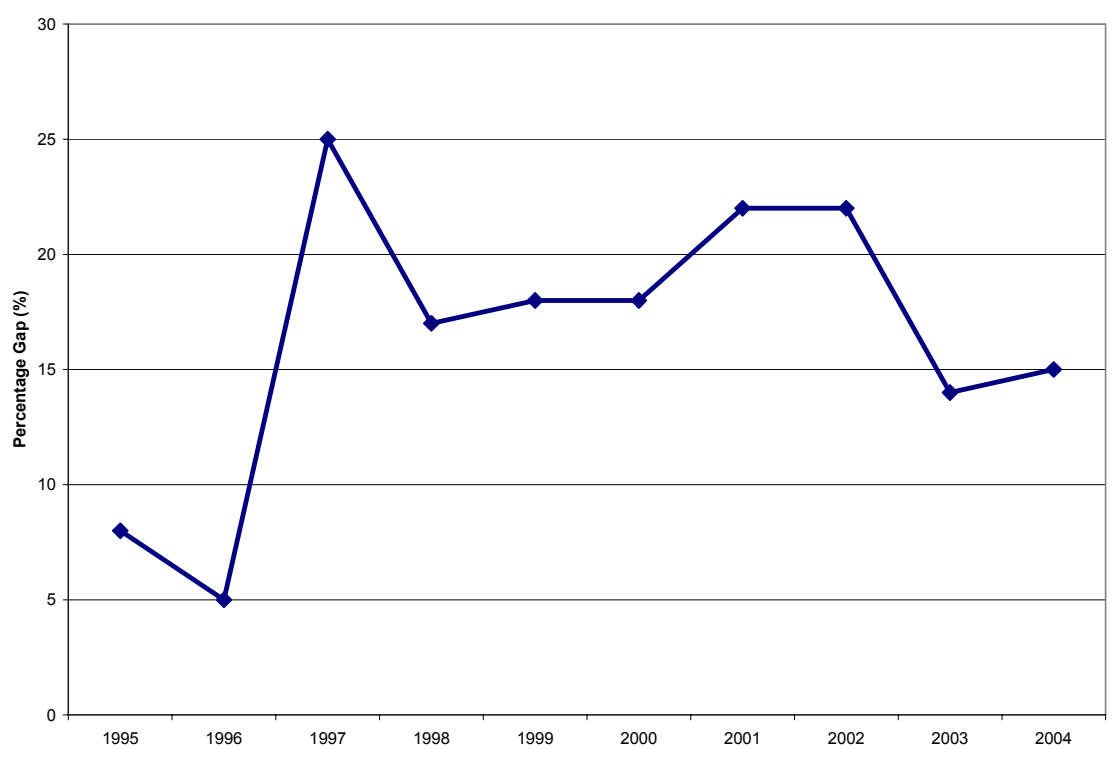


Figure 24: UT Austin Black Application Rates as a Percent of Total 18 Year-Old-Black Population in Texas

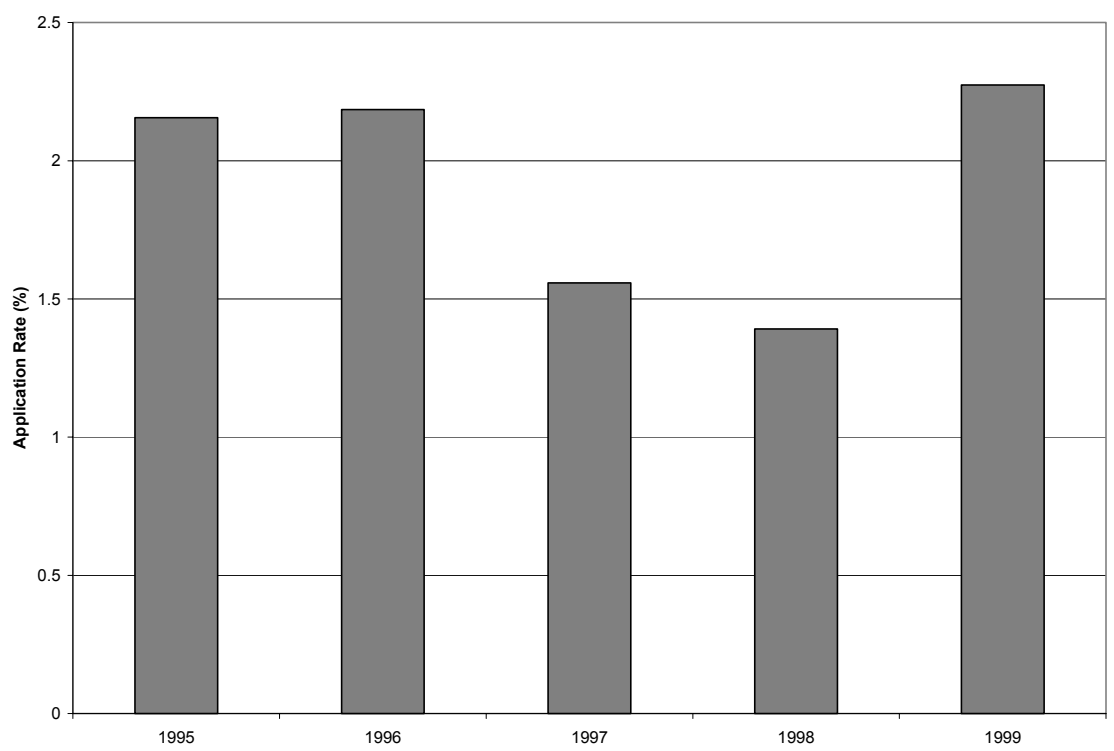

Figure 25: UT Austin Black Admit Rates as a Percent of Total 18-Year-Old Black Population in Texas

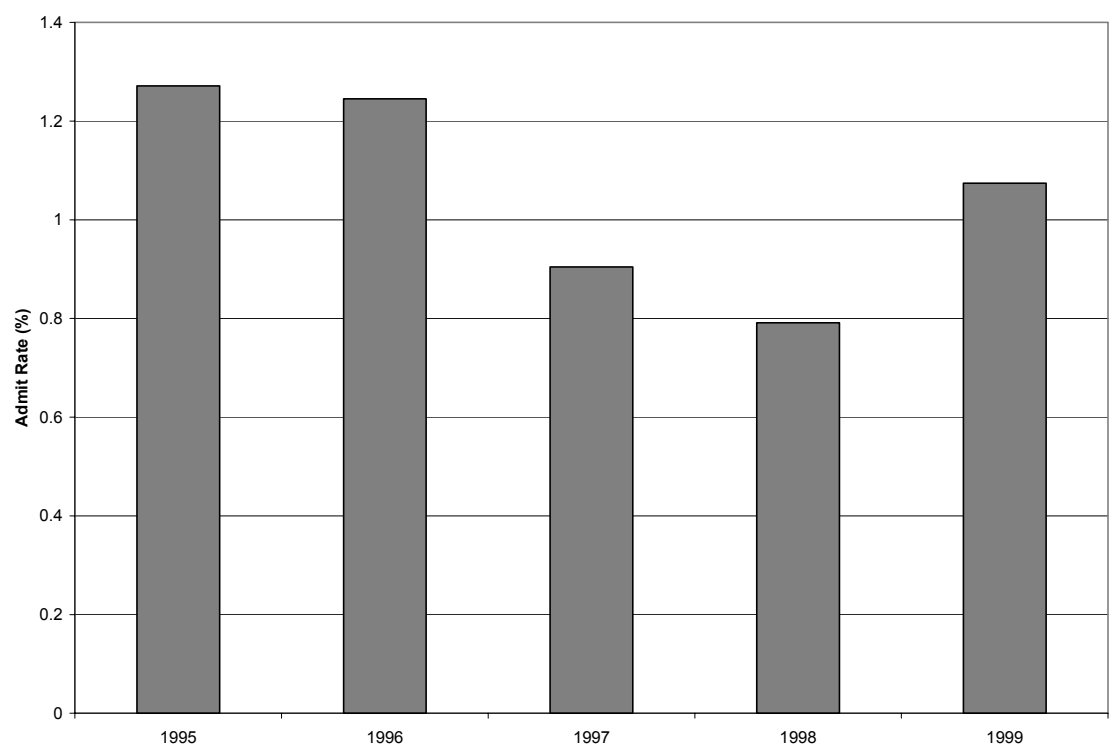


Figure 26: Test Score Distribution-13- \& 14-Year-Old PIAT Math Scores-California and Texas Blacks Pre-Policy vs. Post-Policy

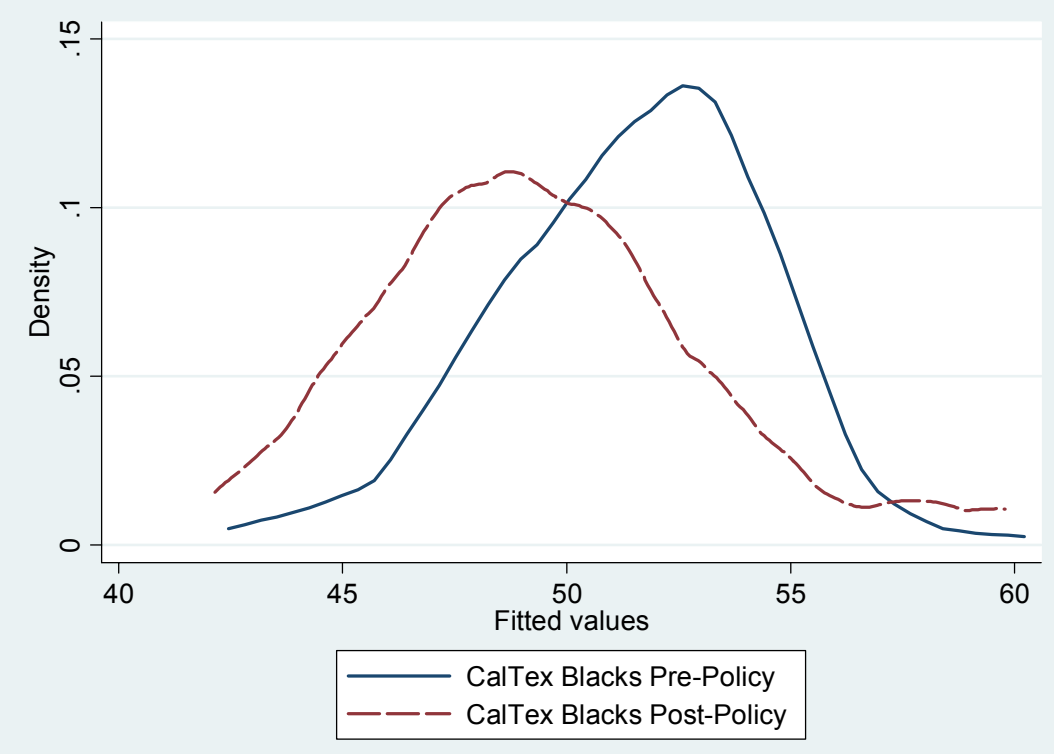

Source: Caldwell (2008)

Figure 27: Test Score Distribution-13- \& 14-Year-Old PIAT Math Scores-Non-Policy State Blacks Pre-Policy vs. Post-Policy

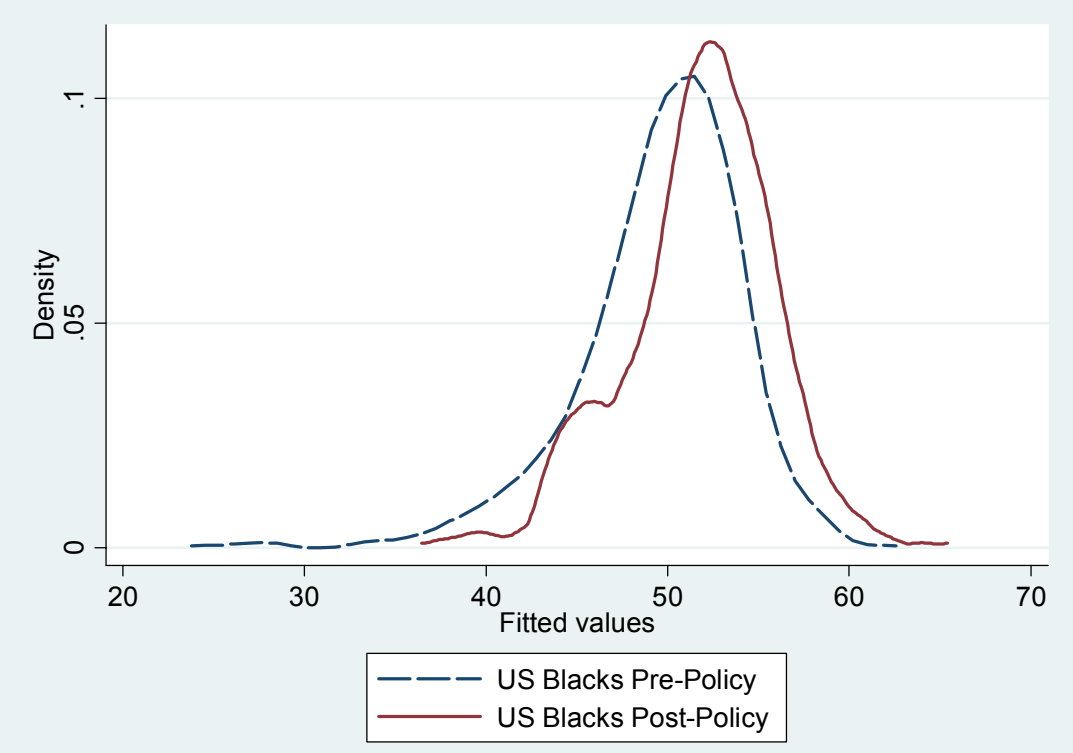

Source: Caldwell (2008) 
Figure 28: Test Score Distribution-13- \& 14-Year-Old PIAT Math

Scores - California and Texas Blacks vs. Whites Pre-Policy

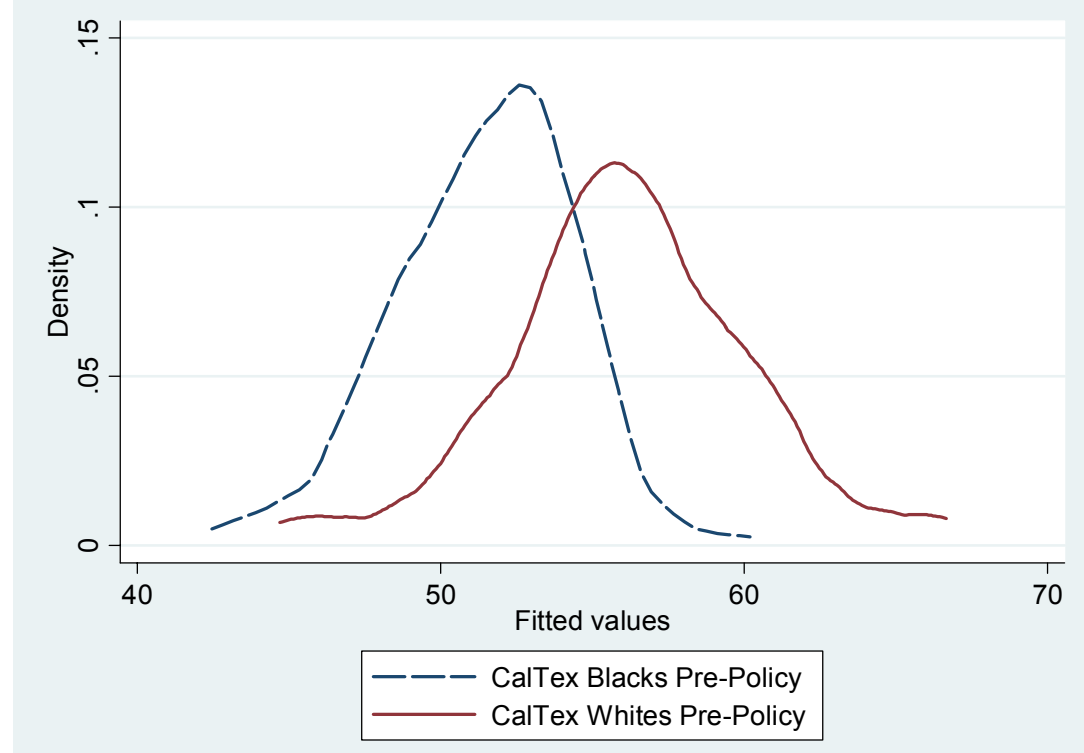

Source: Caldwell (2008)

Figure 29: Test Score Distribution-13- \& 14-Year-Old PIAT Math Scores-California and Texas Blacks vs. Whites Post-Policy

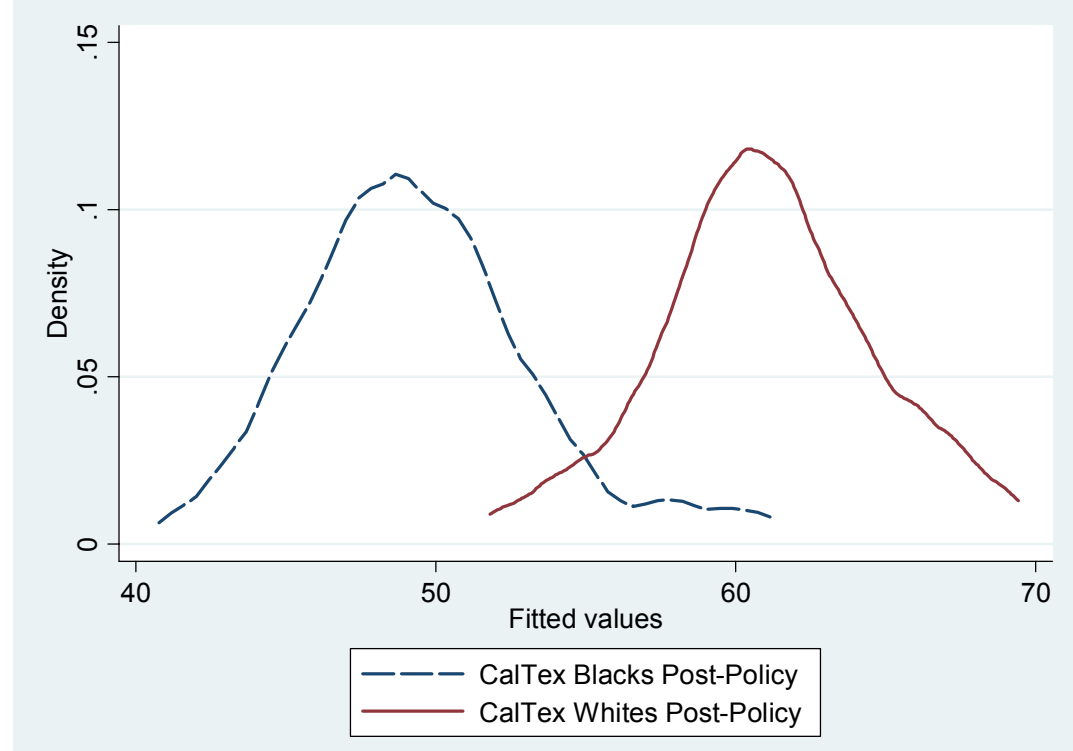

Source: Caldwell (2008) 
Figure 30: Distribution of Growth in PIAT Math Scores 1996 to 2000California and Texas

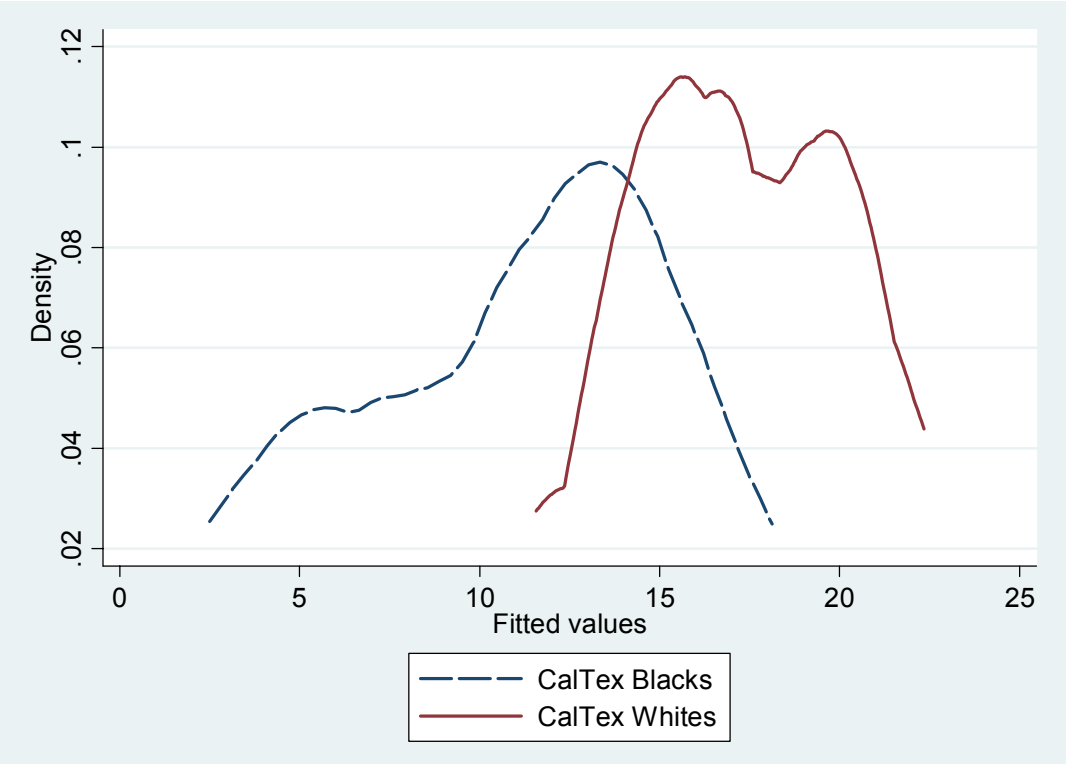

Source: Caldwell (2008)

Figure 31: Distribution of Growth in PIAT Math Scores 1996 to 2000

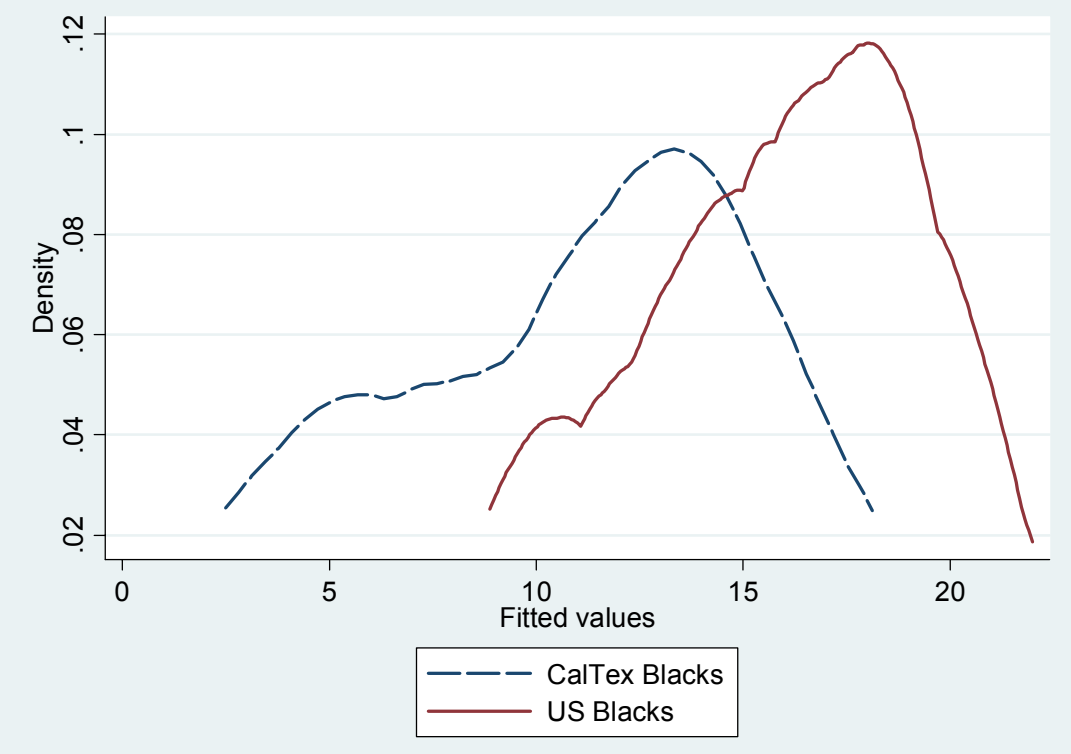

Source: Caldwell (2008) 
Table A1: California Resident Fall Applicants_-First-Time Freshmen

\begin{tabular}{|c|c|c|c|c|c|c|c|}
\hline Year & Total & Native & Black & Hispanic & Asian & White & $\begin{array}{c}\text { Other/ } \\
\text { Unknown }\end{array}$ \\
\hline 1994 & 43389 & 362 & 2149 & 6843 & 14203 & 17357 & 2475 \\
\hline 1995 & 45714 & 459 & 2292 & 7332 & 14377 & 18404 & 2850 \\
\hline 1996 & 48585 & 414 & 2305 & 7191 & 15485 & 19785 & 3405 \\
\hline 1997 & 49030 & 358 & 2141 & 6933 & 16019 & 20870 & 2709 \\
\hline 1998 & 52301 & 408 & 2151 & 7285 & 15912 & 18149 & 8396 \\
\hline 1999 & 55402 & 405 & 2271 & 7709 & 17876 & 22138 & 5003 \\
\hline 2000 & 56309 & 374 & 2376 & 8234 & 18204 & 21747 & 5374 \\
\hline 2001 & 59747 & 379 & 2590 & 9265 & 19207 & 22680 & 5626 \\
\hline 2002 & 62903 & 413 & 2821 & 10121 & 20308 & 23881 & 5359 \\
\hline 2003 & 66774 & 412 & 3108 & 11417 & 20718 & 24555 & 6564 \\
\hline 2004 & 63852 & 425 & 2860 & 11324 & 20202 & 23411 & 5630 \\
\hline 2005 & 65851 & 409 & 2966 & 12313 & 21367 & 24362 & 4434 \\
\hline 2006 & 71011 & 470 & 3307 & 13656 & 24111 & 24926 & 4541 \\
\hline 2007 & 74509 & 479 & 3603 & 15140 & 24778 & 26030 & 4479 \\
\hline
\end{tabular}

Source: University of California StatFinder

Table A2: Fall Applicants-First-Time Freshmen

\begin{tabular}{cccccccc}
\hline Year & Total & Native & Black & Hispanic & Asian & White & $\begin{array}{c}\text { Other/ } \\
\text { Unknown }\end{array}$ \\
\hline 1994 & 47579 & 388 & 2268 & 7086 & 15438 & 19721 & 2678 \\
1995 & 50196 & 495 & 2422 & 7603 & 15647 & 20917 & 3112 \\
1996 & 53112 & 449 & 2426 & 7441 & 16817 & 22266 & 3713 \\
1997 & 54833 & 396 & 2304 & 7199 & 17834 & 24059 & 3041 \\
1998 & 59661 & 463 & 2347 & 7609 & 17911 & 21800 & 9531 \\
1999 & 63837 & 452 & 2476 & 8107 & 20340 & 26685 & 5777 \\
2000 & 65928 & 421 & 2623 & 8686 & 21010 & 26891 & 6297 \\
2001 & 70196 & 448 & 2893 & 9866 & 22352 & 27990 & 6647 \\
2002 & 72826 & 481 & 3119 & 10691 & 23151 & 29125 & 6259 \\
2003 & 75816 & 474 & 3408 & 11951 & 23263 & 29334 & 7386 \\
2004 & 72838 & 484 & 3177 & 11914 & 22961 & 27912 & 6390 \\
2005 & 73865 & 467 & 3239 & 12781 & 23602 & 28696 & 5080 \\
2006 & 80127 & 543 & 3671 & 14194 & 26712 & 29769 & 5238 \\
2007 & 83969 & 546 & 4025 & 15728 & 27516 & 30937 & 5217 \\
\hline
\end{tabular}


Table A3: California Resident Fall Admits-First-Time Freshmen

\begin{tabular}{cccccccc}
\hline Year & Total & Native & Black & Hispanic & Asian & White & $\begin{array}{c}\text { Other/ } \\
\text { Unknown }\end{array}$ \\
\hline 1994 & 36475 & 317 & 1628 & 5672 & 11962 & 14802 & 2094 \\
1995 & 38176 & 392 & 1683 & 6050 & 12037 & 15606 & 2408 \\
1996 & 40035 & 360 & 1629 & 5745 & 12956 & 16484 & 2861 \\
1997 & 40425 & 308 & 1556 & 5740 & 13494 & 17077 & 2250 \\
1998 & 42742 & 316 & 1368 & 5503 & 13519 & 15202 & 6834 \\
1999 & 45017 & 295 & 1454 & 5862 & 14973 & 18313 & 4120 \\
2000 & 46524 & 288 & 1537 & 6397 & 15473 & 18368 & 4461 \\
2001 & 51009 & 313 & 1735 & 7433 & 16659 & 20027 & 4842 \\
2002 & 53686 & 337 & 1891 & 8077 & 17642 & 21180 & 4559 \\
2003 & 57217 & 325 & 2116 & 8983 & 18181 & 21980 & 5632 \\
2004 & 49497 & 290 & 1647 & 8050 & 16555 & 18512 & 4443 \\
2005 & 56505 & 326 & 1961 & 9658 & 18903 & 21781 & 3876 \\
2006 & 62214 & 390 & 2326 & 11198 & 21749 & 22472 & 4079 \\
2007 & 65088 & 409 & 2567 & 12287 & 22362 & 23475 & 3988 \\
\hline Source: University of California StatFinder & & & &
\end{tabular}

Table A4: Fall Admits-First-Time Freshmen

\begin{tabular}{cccccccc}
\hline Year & Total & Native & Black & Hispanic & Asian & White & $\begin{array}{c}\text { Other/ } \\
\text { Unknown }\end{array}$ \\
\hline 1994 & 39101 & 337 & 1699 & 5836 & 12768 & 16232 & 2229 \\
1995 & 41005 & 423 & 1776 & 6237 & 12806 & 17187 & 2576 \\
1996 & 42751 & 383 & 1687 & 5885 & 13736 & 17999 & 3061 \\
1997 & 43940 & 333 & 1633 & 5877 & 14558 & 19067 & 2472 \\
1998 & 46788 & 340 & 1427 & 5655 & 14623 & 17293 & 7450 \\
1999 & 49006 & 312 & 1512 & 6018 & 16116 & 20556 & 4492 \\
2000 & 50937 & 308 & 1619 & 6564 & 16771 & 20783 & 4892 \\
2001 & 55793 & 347 & 1820 & 7711 & 18072 & 22516 & 5327 \\
2002 & 58043 & 369 & 1956 & 8300 & 18934 & 23500 & 4984 \\
2003 & 61426 & 350 & 2184 & 9201 & 19431 & 24259 & 6001 \\
2004 & 53898 & 306 & 1731 & 8308 & 17976 & 20763 & 4814 \\
2005 & 60221 & 352 & 2021 & 9813 & 20077 & 23765 & 4193 \\
2006 & 66789 & 424 & 2399 & 11390 & 23261 & 24854 & 4461 \\
2007 & 69611 & 436 & 2676 & 12497 & 23811 & 25802 & 4389 \\
\hline
\end{tabular}


Table A5: California Resident Fall Enrollees-First-Time Freshmen

\begin{tabular}{cccccccc}
\hline Year & Total & Native & Black & Hispanic & Asian & White & $\begin{array}{c}\text { Other/ } \\
\text { Unknown }\end{array}$ \\
\hline 1994 & 21443 & 208 & 940 & 3353 & 8079 & 7710 & 1153 \\
1995 & 21999 & 248 & 945 & 3432 & 7910 & 8179 & 1285 \\
1996 & 23188 & 237 & 888 & 3209 & 8477 & 8817 & 1560 \\
1997 & 23681 & 183 & 917 & 3131 & 8789 & 9451 & 1210 \\
1998 & 24876 & 168 & 739 & 2948 & 8947 & 8256 & 3818 \\
1999 & 24970 & 140 & 756 & 3233 & 9880 & 9713 & 1248 \\
2000 & 26825 & 161 & 832 & 3479 & 10180 & 9779 & 2394 \\
2001 & 28704 & 164 & 856 & 3864 & 11100 & 10234 & 2486 \\
2002 & 29916 & 159 & 936 & 4222 & 11735 & 10577 & 2287 \\
2003 & 30349 & 139 & 983 & 4450 & 11655 & 10473 & 2649 \\
2004 & 27973 & 142 & 813 & 4189 & 11046 & 9440 & 2343 \\
2005 & 30083 & 144 & 909 & 4652 & 12254 & 10165 & 1959 \\
2006 & 33540 & 171 & 1072 & 5481 & 14058 & 10687 & 2071 \\
2007 & 33577 & 172 & 1244 & 5874 & 13953 & 10473 & 1861 \\
\hline
\end{tabular}

Table A6: Fall Enrollees-First-Time Freshmen

\begin{tabular}{cccccccc}
\hline Year & Total & Native & Black & Hispanic & Asian & White & $\begin{array}{c}\text { Other/ } \\
\text { Unknown }\end{array}$ \\
\hline 1994 & 22205 & 216 & 963 & 3402 & 8321 & 8117 & 1186 \\
1995 & 22857 & 262 & 972 & 3480 & 8147 & 8659 & 1337 \\
1996 & 23958 & 242 & 903 & 3245 & 8709 & 9262 & 1597 \\
1997 & 24717 & 191 & 948 & 3165 & 9097 & 10048 & 1268 \\
1998 & 26115 & 176 & 760 & 2986 & 9285 & 8901 & 4007 \\
1999 & 27204 & 143 & 774 & 3269 & 10279 & 10391 & 2348 \\
2000 & 28215 & 164 & 867 & 3526 & 10588 & 10545 & 2525 \\
2001 & 30146 & 175 & 879 & 3950 & 11536 & 10998 & 2608 \\
2002 & 31200 & 170 & 957 & 4284 & 12113 & 11279 & 2397 \\
2003 & 31530 & 144 & 1001 & 4497 & 12009 & 11137 & 2742 \\
2004 & 29127 & 143 & 836 & 4260 & 11428 & 10033 & 2427 \\
2005 & 30996 & 152 & 926 & 4678 & 12564 & 10646 & 2033 \\
2006 & 34763 & 179 & 1088 & 5521 & 14472 & 11337 & 2166 \\
2007 & 34658 & 177 & 1271 & 5909 & 14301 & 11054 & 1946 \\
\hline
\end{tabular}


Table A7: UT Austin Fall Applicants-First-Time Freshmen

\begin{tabular}{cccccccc}
\hline Year & Total & Native & Black & Hispanic & Asian & White & $\begin{array}{c}\text { Other/ } \\
\text { Unknown }\end{array}$ \\
\hline 1995 & 15442 & 86 & 795 & 2212 & 2055 & 9516 & 778 \\
1996 & 17263 & 119 & 809 & 2492 & 2363 & 10584 & 896 \\
1997 & 14682 & 65 & 620 & 1889 & 2153 & 8988 & 967 \\
1998 & 15531 & 84 & 596 & 2106 & 2326 & 9387 & 1032 \\
1999 & 17797 & 79 & 957 & 2615 & 2512 & 10406 & 1228 \\
2000 & 19562 & 98 & 1073 & 2763 & 2643 & 11547 & 1438 \\
2001 & 20025 & 115 & 999 & 2998 & 3012 & 11164 & 1737 \\
2002 & 20280 & 96 & 1080 & 3165 & 3053 & 11388 & 1498 \\
2003 & 22748 & 108 & 1275 & 3822 & 3198 & 12823 & 1522 \\
2004 & 21336 & 116 & 1375 & 3827 & 3021 & 11348 & 1649 \\
\hline
\end{tabular}

Source: UT Austin Office of Institutional Research

Table A8: UT Austin Fall Admits-First-Time Freshmen

\begin{tabular}{cccccccc}
\hline Year & Total & Native & Black & Hispanic & Asian & White & $\begin{array}{c}\text { Other/ } \\
\text { Unknown }\end{array}$ \\
\hline 1995 & 10059 & 51 & 469 & 1599 & 1395 & 6353 & 192 \\
1996 & 10517 & 58 & 461 & 1617 & 1500 & 6571 & 310 \\
1997 & 11458 & 49 & 360 & 1421 & 1821 & 7492 & 315 \\
1998 & 10777 & 49 & 339 & 1393 & 1780 & 6931 & 285 \\
1999 & 10893 & 39 & 452 & 1498 & 1819 & 6802 & 283 \\
2000 & 11413 & 51 & 461 & 1518 & 1862 & 7027 & 494 \\
2001 & 11024 & 52 & 380 & 1513 & 1941 & 6720 & 418 \\
2002 & 11719 & 49 & 431 & 1654 & 2112 & 7067 & 406 \\
2003 & 9967 & 34 & 397 & 1572 & 1775 & 5826 & 363 \\
2004 & 10343 & 43 & 511 & 1741 & 1800 & 5851 & 397 \\
\hline
\end{tabular}

Source: UT Austin Office of Institutional Research 
Table A9: UT Austin Fall Enrollees-First-Time Freshmen

\begin{tabular}{cccccccc}
\hline Year & Total & Native & Black & Hispanic & Asian & White & $\begin{array}{c}\text { Other/ } \\
\text { Unknown }\end{array}$ \\
\hline 1995 & 6352 & 28 & 309 & 935 & 904 & 4081 & 95 \\
1996 & 6430 & 34 & 266 & 932 & 942 & 4159 & 97 \\
1997 & 6644 & 33 & 163 & 807 & 1078 & 4460 & 103 \\
1998 & 6000 & 32 & 165 & 762 & 1034 & 3928 & 79 \\
1999 & 6427 & 22 & 251 & 861 & 1130 & 4084 & 79 \\
2000 & 6664 & 28 & 243 & 877 & 1158 & 4139 & 219 \\
2001 & 6340 & 26 & 205 & 832 & 1240 & 3864 & 173 \\
2002 & 6862 & 31 & 232 & 935 & 1316 & 4196 & 152 \\
2003 & 5986 & 19 & 237 & 926 & 1029 & 3314 & 161 \\
2004 & 5965 & 24 & 275 & 1024 & 1082 & 3386 & 174 \\
\hline
\end{tabular}

Source: UT Austin Office of Institutional Research

Table A10: California Resident Fall ApplicantsFirst Time Freshmen-Berkeley

\begin{tabular}{|c|c|c|c|c|c|c|c|}
\hline Year & Total & Native & Black & Hispanic & Asian & White & $\begin{array}{c}\text { Other/ } \\
\text { Unknown }\end{array}$ \\
\hline 1994 & 17981 & 130 & 1026 & 2301 & 7444 & 5953 & 1127 \\
\hline 1995 & 19458 & 177 & 1129 & 2603 & 7659 & 6563 & 1327 \\
\hline 1996 & 21678 & 157 & 1154 & 2698 & 8596 & 7360 & 1713 \\
\hline 1997 & 22485 & 117 & 1099 & 2742 & 9201 & 7905 & 1421 \\
\hline 1998 & 24447 & 148 & 1164 & 2977 & 9062 & 7129 & 3967 \\
\hline 1999 & 24865 & 136 & 1038 & 2612 & 9986 & 8552 & 2541 \\
\hline 2000 & 26141 & 146 & 1190 & 3214 & 10441 & 8442 & 2708 \\
\hline 2001 & 28145 & 169 & 1296 & 3697 & 11266 & 8874 & 2843 \\
\hline 2002 & 29234 & 166 & 1407 & 4014 & 11725 & 9306 & 2616 \\
\hline 2003 & 30571 & 166 & 1564 & 4418 & 11738 & 9555 & 3130 \\
\hline 2004 & 30407 & 159 & 1405 & 4562 & 11879 & 9561 & 2841 \\
\hline
\end{tabular}


Table A11: California Resident Fall AdmitsFirst Time Freshmen-Berkeley

\begin{tabular}{cccccccc}
\hline Year & Total & Native & Black & Hispanic & Asian & White & $\begin{array}{c}\text { Other/ } \\
\text { Unknown }\end{array}$ \\
\hline 1994 & 7487 & 93 & 517 & 1304 & 2697 & 2418 & 458 \\
1995 & 7771 & 118 & 566 & 1434 & 2572 & 2564 & 517 \\
1996 & 8056 & 100 & 573 & 1326 & 2734 & 2709 & 614 \\
1997 & 7426 & 59 & 545 & 1247 & 2609 & 2423 & 543 \\
1998 & 7305 & 27 & 236 & 619 & 2785 & 2370 & 1268 \\
1999 & 7334 & 38 & 294 & 728 & 2909 & 2559 & 806 \\
2000 & 7637 & 41 & 338 & 885 & 2965 & 2550 & 858 \\
2001 & 7949 & 48 & 323 & 995 & 3098 & 2601 & 884 \\
2002 & 7630 & 41 & 319 & 1001 & 3058 & 2503 & 708 \\
2003 & 7767 & 45 & 304 & 1013 & 3052 & 2521 & 832 \\
2004 & 7849 & 40 & 216 & 928 & 3171 & 2722 & 772 \\
\hline
\end{tabular}

Source: University of California StatFinder

Table A12: California Resident Fall ApplicantsFirst Time Freshmen-UCLA

\begin{tabular}{|c|c|c|c|c|c|c|c|}
\hline Year & Total & Native & Black & Hispanic & Asian & White & $\begin{array}{c}\text { Other/ } \\
\text { Unknown }\end{array}$ \\
\hline 1994 & 21428 & 124 & 1191 & 3389 & 9008 & 6557 & 1159 \\
\hline 1995 & 23002 & 154 & 1387 & 3707 & 9090 & 7235 & 1429 \\
\hline 1996 & 25763 & 170 & 1450 & 3783 & 10335 & 8262 & 1763 \\
\hline 1997 & 25984 & 143 & 1272 & 3619 & 10743 & 8827 & 1380 \\
\hline 1998 & 29067 & 178 & 1247 & 3960 & 10814 & 8414 & 4454 \\
\hline 1999 & 30962 & 179 & 1308 & 4055 & 12066 & 10500 & 2854 \\
\hline 2000 & 32261 & 176 & 1480 & 4574 & 12594 & 10389 & 3048 \\
\hline 2001 & 34422 & 181 & 1531 & 5256 & 13218 & 10949 & 3287 \\
\hline 2002 & 37516 & 198 & 1757 & 6100 & 14161 & 12134 & 3166 \\
\hline 2003 & 39287 & 196 & 1916 & 6628 & 14465 & 12261 & 3821 \\
\hline 2004 & 37656 & 207 & 1764 & 6552 & 14203 & 11581 & 3349 \\
\hline
\end{tabular}


Table A13: California Resident Fall Admits-

First Time Freshmen-UCLA

\begin{tabular}{|c|c|c|c|c|c|c|c|}
\hline Year & Total & Native & Black & Hispanic & Asian & White & $\begin{array}{c}\text { Other/ } \\
\text { Unknown }\end{array}$ \\
\hline 1994 & 10937 & 99 & 700 & 1999 & 4402 & 3185 & 552 \\
\hline 1995 & 9920 & 105 & 661 & 1994 & 3734 & 2839 & 587 \\
\hline 1996 & 10132 & 97 & 606 & 1716 & 3774 & 3229 & 710 \\
\hline 1997 & 9622 & 76 & 488 & 1476 & 3812 & 3172 & 598 \\
\hline 1998 & 9699 & 44 & 294 & 969 & 3879 & 2999 & 1514 \\
\hline 1999 & 9313 & 37 & 313 & 1022 & 3897 & 3097 & 947 \\
\hline 2000 & 9886 & 47 & 325 & 1152 & 4066 & 3289 & 1007 \\
\hline 2001 & 9876 & 43 & 326 & 1257 & 4037 & 3178 & 1035 \\
\hline 2002 & 9427 & 38 & 337 & 1310 & 3961 & 2936 & 845 \\
\hline 2003 & 9496 & 32 & 277 & 1306 & 3949 & 2959 & 973 \\
\hline 2004 & 8777 & 33 & 215 & 1147 & 3664 & 2859 & 859 \\
\hline
\end{tabular}

